Synthesis, part of a Special Feature on The Privilege to Fish

\title{
Fishful Thinking: Rhetoric, Reality, and the Sea Before Us
}

\author{
$\underline{\text { Tony J. Pitcher }}^{1}$ and Mimi E. Lam ${ }^{2}$
}

\begin{abstract}
Fisheries science and management have been shrouded in controversy and rhetoric for over 125 yrs. Human reliance on fish through history (and even prehistory) has impacted the sea and its resources. Global impacts are manifest today in threatened food security and vulnerable marine ecosystems. Growing consumer demand and subsidized industrial fisheries exacerbate ecosystem degradation, climate change, global inequities, and local poverty. Ten commonly advocated fisheries management solutions, if implemented alone, cannot remedy a history of intense fishing and serial stock depletions. Fisheries policy strategies evaluated along five performance modalities (ecological, economic, social, ethical, and institutional) suggest that composite management strategies, such as ecosystem-based management and historically based restoration, can do better. A scientifically motivated solution to the fisheries problem can be found in the restorable elements of past ecosystems, if some of our present ideology, practices, and tastes can be relinquished for this historical imperative. Food and social security can be enhanced using a composite strategy that targets traditional food sources and implements customary management practices. Without binding laws, however, instituting such an ethically motivated goal for fisheries policy can easily be compromised by global market pressures. In a restored and productive ecosystem, fishing is clearly the privilege of a few. The realities of imminent global food insecurity, however, may dictate a strategy to deliberately fish down the food web, if the basic human right to food is to be preserved for all.
\end{abstract}

Key Words: back-to-the-future; ecological ethics; ecosystem restoration; fisheries management; fishing down the food web; food security; policy goals; the sea ahead; trade-offs

\section{INTRODUCTION}

Fisheries science and management (Pitcher et al. 1998) are ensnared within a 125-year-old controversy (Sims and Southward 2006) over the status (Hilborn et al. 2003) and impacts (Pauly et al. $1998 a, 2005)$ of the fishing enterprise. Some regard fisheries as largely successful (e.g., Beddington et al. 2007, Hilborn 2007a,c,d), with only "minor" ecosystem impacts (Sibert et al. 2006). Other scientists report serious problems with modern commercial fisheries: inadequate data (Watson and Pauly 2001, Pauly 2007), poor compliance (Pitcher et al. 2008, 2009a,b), inappropriate incentives (Hilborn et al. 2004, Grafton et al. 2006, Hilborn 2007b, Rosenberg 2009), incomplete valuation (Sumaila 2005, 2007, Lam and Sumaila 2008), failed management (Walters 2007), vague policy goals (Pauly et al. 2003, Pitcher and Ainsworth 2008), dysfunctional institutions (Hanna 1998, Hilborn et al. 2005a, Acheson 2006), and ineffective governance (Sutinen and Soboil 2003, Kooiman et al. 2005, Crowder et al. 2006, Grafton et al. 2007, Jentoft 2007, Bromley 2008, Lam and Pauly 2010). A surging human population and widening socioeconomic disparity, both among and within nations, raises the specter of global food security shortfalls and unsustainable exploitation of natural resources. Modern consumer demand, heavy industrialization, international markets, and government subsidies exacerbate global inequities that challenge our ability to govern complex fishery systems (Garcia and Charles 2008).

Less fish brings plenty of advice on how to improve fisheries (e.g., Francis et al. 2007, Roberts 2007) despite sparse diagnostic data. More beguiling management strategies tend to be utopian, narrow, and prescriptive, rather than practical, holistic, and adaptive. They generally take this form: "If only we could do " $x$," then all will be well with fisheries;" but merely wishing for something like " $x$," however 
attractive, does not make it so. This "fishful thinking" reflects an aging chestnut in philosophy, known alternatively as "Hume's Guillotine" (Hume 1740) or the "Naturalistic Fallacy" (Moore 1903), which states that you cannot get an "is" from an "ought," an old adage that has generated vast commentary in philosophy but is likely unknown in fisheries science. Indeed, the fisheries literature is full of authors "fishfully" moving from "oughts" to "ises", with simple management "cures" and policy "prescriptions": in truth, the reality of modern fisheries as complex, dynamic, and coupled humanand-natural systems (Liu et al. 2007a,b) is missed by such well-intended, but misguided rhetoric.

\section{FISHFUL THINKING: FALLACIES OF SIMPLE SOLUTIONS TO A COMPLEX PROBLEM}

Despite authors who have recently emphasized that the complexities of fisheries management cannot be solved by "panaceas" (Ostrom 2007) or "technical fixes" (Degnbol et al. 2006), simple solutions and fallacious arguments are still promulgated. It might be thought that simple versions of these arguments are but "straw men" (logical fallacies where irrelevant topics are presented to divert attention from the original issue), propped up so that they may be easily knocked down; however, presenting and refuting a weakened form of another's arguments is valid and not a straw-man argument. Here, we describe ten common "if-only" fishery palliatives that can fall foul of Hume's Guillotine. For each case, we present the basic "weak" form of the panacea or technical fix, refute this weaker proposition, then follow with a "strong," more nuanced view of the augmented management strategy. The summary below, although thorough, is not intended to be definitive, but rather to illustrate the streams of management alternatives currently flowing into the fisheries literature and policy debates. Only by discarding fallacious arguments can we better explore viable policy options that can begin to address the real complexity of modern fisheries and societal challenges.

\section{Privatization of resources}

Currently in vogue and the topic analyzed by this Special Feature is the fisheries economists' nirvana: "If only we could privatize fishery resources, then all will be well with fisheries" (Grafton et al. 2006,
Beddington et al. 2007, Costello et al. 2008). This trend toward privatization of fishery resources (Neher 1996, Hannesson 1998, 2005) arose from economists extending the legal concept of property rights to public-trust natural resources (for critiques, see Bromley 2005, 2008, 2009), where fishermen are given "ownership rights" or individual transferable quotas (ITQs) to harvest exclusively an allocation of a nation's fishery resources. The theory of ITQs (Grafton 1996, Arnason 1998) is that a market will be set up in which harvest rights can be traded (Christy 1997), giving fishermen not only "ownership" but also a financial incentive to manage the fishery resources wisely, thus ensuring long-term sustainability (Fujita et al. 1998). Proponents of ITQs argue this will reduce conflict over scarce resources, end the race for fish, and fund management, enforcement, and research, free of public subsidy (Grafton et al. 2006). But, in practice, many legal issues about what is actually owned and how remain unresolved (Eythórsson 2000, Macinko and Bromley 2002, 2004, Libecap 2008, Wyman 2008). And with highly valuable resources, even ITQs do not eliminate cheating and illegal fishing: a classic example is the destruction of the Chilean squat lobster fishery under ITQs (Castilla et al. 2007).

Fundamentally, ITQs and allied "free-market" approaches (Jennings 2007) suffer from the "ownership-promotes-stewardship" fallacy (Bromley 2008, 2009). As assigned catch shares of the total allowable catch (TAC), ITQs are not property rights but rather dedicated access privileges (Macinko and Bromley 2002, 2004, Fujita and Bonzon 2005, Hilborn 2007a) and thus only limit entry and access to fishery resources. Moreover, ITQs suffer from social justice issues (Schreiber 2001, Lam and Pauly 2010) in the initial allocation of harvest quotas and subsequent concentration of quotas to large-scale fishing enterprises, which can be exacerbated by leasing (Pinkerton and Edwards 2009). Iceland, an early ITQ adopter, has witnessed improved economic efficiency and reduced fleet size but suffers the social costs of increasing overall fishing capacity, concentrating quotas into larger firms, marginalizing small communities, and escalating conflicts within small-scale fisheries and crew (Jennings 1999, Eythórsson 2000, Alcock 2002, Coastal Communities News 2002). With appropriate TACs, better enforcement and monitoring, and an ecosystem-based approach, the track record of ITQs suggests that they can improve fisheries management, but not always (Chu 2008, 
Branch 2009): indeed, early ITQ proponents (Hilborn et al. 2005b) admitted that "[r]ights-based management is not a silver bullet, and is probably not appropriate for all fisheries." An analysis by Clark et al. (2010: 209) states that "[t]he 'optimists' maintain that there are no effective limits to privatization and that the decades old fear that privatization could, in some cases, lead to resource extinction are of theoretical interest only. We argue that these fears are, regrettably, not baseless and that there are definite limits to socially desirable privatization." And so the debate over incentivebased vs. regulatory-based management approaches continues (Gibbs 2009).

\section{Total Economic Valuation (TEV)}

Separate from market transactions is the need to capture the non-market value of fishery resources (Sumaila 2005): "If only we could capture the total economic value (TEV) of ecosystem services and future generations, then all will be well with fisheries." Only by valuing the market and nonmarket benefits that aquatic resources contribute to society (National Research Council of the National Academies 2004) will resilient marine ecosystems (Levin et al. 1998) be sustained with healthy and productive fish stocks. Provisioning, regulating, cultural, and supporting global ecosystem services (Daily et al. 1997, Millennium Ecosystem Assessment 2005) have been valued at US\$33 trillion per year (Costanza et al. 1997). But placing financial value on ecosystem services through market-based instruments (Brown et al. 2007) may not bode well for nature or the poor, without appropriate scientific understanding, legal frameworks, and market mechanisms. Environmental markets with the goal of preserving or restoring ecosystem services may actually accelerate their degradation (Palmer and Filoso 2009) and exacerbate global wealth disparities. Although TEV endows the ecosystem that supports the standing fish biomass with value beyond its marketable landed catch value, including option, existence, and bequest values, it is based on individual preferences aggregated for society and so does not value public goods with societal considerations of ecological sustainability or social equity (Dasgupta and Mäler 2004). Intergenerational equity foregoes rewards to present generations to benefit future generations, who would value future resources more, and so discount less than present generations (Sumaila 2004, Sumaila and Walters 2005). In the case of
Newfoundland cod, which suffered chronic overfishing and a notorious collapse in the early 1990s (Rose 2007), intergenerational discounting would have rendered uneconomic the actual harvest profile of the healthy cod stocks present in 1985, favoring a more conservative, sustainable long-term strategy, whereas conventional discounting, with the discount rate set to market interest, advocated heavy fishing (Ainsworth and Sumaila 2005).

In theory, TEV captures the non-market value of fishery resources, but in practice, as ecosystem goods and services become scarcer and more valuable, they are prone to conversion to market values that may compromise the basic needs of the poor while creating opportunities for the rich. Consider the dilemma faced by an artisanal fisherman living in poverty: should he curb his fishing pressure and think of the ecosystem or future generations when he needs to feed his family today? Or in wealthy nations, how will individuals and societies shift to value the future or nonconsumptive uses when the global economy is driven by financial incentives based on resources and commodities valued in today's market? George Sugihara and colleagues (May et al. 2008) have proposed a futures market in fisheries (Dalton 2005, 2006) with an "Ocean Resource Exchange" trading in two types of derivatives: futures contracts for a percentage of a fisherman's catch at an agreed price at a specified future time and one for trading fish quotas today. With global society still reeling from the financial collapse of December 2008, such ventures are less than alluring, but even apart from a more risk-averse mentality, this would be riddled with uncertainty and create a perverse incentive for venture capitalists to reduce the supply of fish being traded to raise their future stock value. To date, most simulations of application of pure economic goals for fisheries result in the rapid destruction of biodiversity and resources (e.g., Ainsworth et al. 2008a), and moreover, all known real-world examples overwhelmingly support this conclusion. Lam and Sumaila (2008) have proposed a socioeconomic framework for fisheries valuation and analysis that attempts to capture, in addition to the financial, the ecological, social, and cultural value of fish, as well as be practical for management and policy. Meanwhile, traditional Pacific Northwest indigenous societies have a sevengenerational, holistic perspective, based on their beliefs in reincarnation and that all ecosystem elements are relatives (Trosper 2009). 


\section{Laissez-faire}

A common rallying call from fishermen is "If only commercial fishermen were allowed to manage their own fishing, free from governmental interference, then all will be well with fisheries." This laissez-faire strategy presumes that fishermen can influence the market to favor the most efficient allocation of fishery resources and evolve sustainable fisheries. For example, it was argued that the Newfoundland cod collapse (McCay and Finlayson 1995) might have been averted if fishermen were allowed to self-regulate using their inshore fishermen's knowledge, all but ignored by the Canadian fishery agency responsible (Matthews 1995). This argument has been extended to letting the industry, under protection against new licenses, reduce fishing effort by financing buybacks of licenses, treated as fully transferable catch rights (Martell et al. 2008). However, private-interest groups with political power, such as commercial fishermen, often influence fisheries management and policy decisions against conservation (Rosenberg 2007), creating perverse economic incentives (Lam and Pauly 2010), notably subsidies (Munro and Sumaila 2002, Clark et al. 2005, Sumaila et al. 2007), which enable fishing enterprises to fish when it would be otherwise uneconomical if costs and benefits were strictly market determined or "internalized." Fishermen, behaving rationally from the perspective of their private interests, can also collectively destroy a resource if the financial benefits of extracting the resource today exceed the value, to the fishermen, of maintaining a healthy stock tomorrow (Clark 1973, Clark et al. 2010). So the laissez-faire strategy in fisheries management is a two-edged sword, as both governmental interference or favoritism and fishermen's financial incentives can collapse a stock.

\section{Selective fishing technology}

Another utopian, industry-driven solution is "If only we could improve fishing technology, then all will be well with fisheries." Fishing gear selected for regulated species, sizes, and ages (Kennelly and Broadhurst 2002, Kennelly 2007) and no damage to benthic habitats (as caused by trawling and dredging) can reduce harm of overfishing to stocks and ecosystems caused by fisheries discards, unwanted by-catch, and collateral damage to habitats. But fishing technology has evolved over millennia to increase fish catch and the number of target species caught (Pitcher 2001), to travel greater distances to new habitats (Roberts 2007) and greater depths (Morato et al. 2006). Enhanced refrigeration (Roberts 2007) and other preservation methods (Sivertsvik et al. 2002) can also store caught fish for longer periods. The effect has been serial depletion of species and fished areas (e.g., Berkes et al. 2006, Branch et al. 2006), while fishermen benefit from globalization of markets (Pauly and Maclean 2003). So, even if selective fishing technology and harvest quota regulations are in place, improved fishing technology alone is unlikely to address conservation issues. The motivation of fishermen to enhance fishing technology is to increase profits from fish caught by catching and storing fish more efficiently and effectively. Poor compliance will continue to be an issue in by-catch reduction unless management creates incentives to encourage the uptake of selective fishing technology into fishing practices. Alternative rewards that can compete with economic incentives of fishermen to discard bycatch might be the adoption of improved fishing gear design that can make the fishing enterprise more efficient economically, while conserving fish.

\section{Marine Protected Areas (MPAs)}

An alternative to selective fishing technology is to ban fishing selectively: "If only we could set up extensive marine protected areas (Ballantine 1997, Lubchenco et al. 2003, Roberts et al. 2005), then all will be well with fisheries (Roberts et al. 2001)." Marine protected areas (MPAs) are protected areas of the ocean where human activities are restricted, typically to achieve conservation objectives, such as preserving marine biodiversity (Sumaila and Charles 2002, Bohnsack et al. 2004). "No-take" marine reserves are MPAs permanently closed to all fishing and other extractive uses (Ballantine 1997), whereas zones of integrated ocean management are MPAs that regulate uses within a zoned area or network of zones (Lubchenco et al. 2003). Marine protected areas serve as ecological "insurance policies" or "hedges" against scientific uncertainty, as in stock assessments (Lauck et al. 1998). They are not the panacea originally envisaged (Pauly et al. 2002, Norse et al. 2003) but are useful ecosystem-based management tools for marine conservation and sustainable fisheries. By protecting against ecological risks, MPAs can encourage growth in depleted species, restore fish 
habitats, provide protected source and/or settlement zones for larvae, and create spill-over areas, enhancing recruitment and fishing activity at their boundaries. Although trophic cascades may result from higher population densities inside the MPA, studies suggest greater benefits from larger MPAs and for MPA networks that take advantage of oceanographic linkages (e.g., Roberts 2001, 2005, Russ 2002, Gell and Roberts 2003, Wood and Dragicevic 2007).

Despite their vaunted advantages, MPAs have not been hugely successful, being too few and too small and ecological recovery and implementation too slow, in arresting the decline of marine ecosystems (see, e.g., Agardy et al. 2003, Caddy and Seijo 2005, Jones 2007, Ballentine and Langlois 2008). As of 31 December 2006, only $0.65 \%$ of the world's oceans and $1.6 \%$ of the marine areas under national jurisdiction were nominally protected, with $0.08 \%$ and $0.2 \%$ no-take (Wood 2007, Wood et al. 2008). Attempts to establish MPAs have exposed complexity in several dimensions that policy makers must negotiate with affected communities: ecological (Allison et al. 1998, Guénette et al. 1998), socioeconomic (Sumaila and Charles 2002), and sociopolitical (Guénette et al. 2000, Mascia 2003, Agardy 2005). Effective selection, design, and management of MPAs require both local community and centralized government authority, with scientific and socioeconomic objectives clearly identified, combined with "best-practice" reference points (Sainsbury and Sumaila 2003) and enforceable management priorities (Jones 2002, 2007). An analysis of compliance of the top 53 fishing nations with the MPA provisions of the United Nations' "Code of Conduct for Responsible Fisheries" (Pitcher et al. 2009b) awarded only 15\% "good," and over 80\% "fail" grades.

\section{Single-species stock assessment}

A less drastic governmental intervention than MPAs, conventional single-species management strategies hold the implicit belief that "If only we could get stock assessments right, then all will be well with fisheries" (e.g., Beverton and Holt 1957, Walters and Maguire 1996, Punt et al. 2008). Quantitative fishery scientists generally prescribe complex models with real-time data acquisition of fish population dynamics data to monitor stock responses to varying environmental and fishing pressures (e.g., Sainsbury 1998, Walters and Martell
2004). By "confronting" (Ludwig et al. 1993) all sources of uncertainty with Bayesian models (e.g., Punt and Hilborn 1997) and statistical decision analysis (e.g., Peterman et al. 1998), it is implied that rigorous modeling (Schnute and Richards 1994) will give reasonably accurate snapshots of fish biomass. Appropriate harvest allocations can then be set at sustainable yields (Rosenberg et al. 1993) for successful management within the fishing industry (Hilborn $2007 a, c, d$ ). However, singlespecies fisheries science neglects complex multispecies and human interactions (Mace 2001), such that stock assessment analyses, although quantitative, often miss critical factors in the real fisheries dynamics. And although sophisticated singlespecies, density-dependent population dynamic models are used routinely in fisheries assessments, they are data intensive and parameter rich, yet the overwhelming majority of the world's fisheries are data poor. Two robust solutions to these limitations are to use multi-species or ecosystem models, predictions of which can and often do differ from single-species assessments (e.g., Walters et al. 2005), and to approximate yield estimates from lifehistory parameters (e.g., Forrest et al. 2008). But often the institutional hurdle of implementing the TAC estimated from such models, however sophisticated, proves infeasible.

\section{Ecosystem-based management (EBM)}

Going beyond conventional single-species approaches, "If only we could apply ecosystem-based management (Food and Agriculture Organization (FAO) 2003a, Pikitch et al. 2004, McLeod et al. 2005), then all will be well with fisheries." Ecosystem-based management (EBM) focuses on ecosystem links (Larkin 1996) to preserve the structural integrity, healthy functioning, and resilient processes of marine ecosystems and strives to achieve regional cooperation in their management (Sherman 1995). More comprehensive than single-species or sectoral management, from both scientific and governance perspectives (Sissenwine and Mace 2003, Ruckelshaus et al. 2008), EBM is a holistic approach that considers the integrated human-natural ecosystem (Grumbine 1994, 1997, Maguire et al. 1995, Mangel et al. 1996, Mooney 1998, Carpenter and Gunderson 2001, Liu et al. 2007a,b) to sustain vital services to humans (Browman and Stergiou, 2004, 2005, Rosenberg and McLeod 2005). Closely allied to EBM is the Ecosystem Approach to Management (EAM, FAO 
2003b), which differs only in its emphasis on retaining as much of the single-species approach as possible. This EAM has been recently extended to examine the human context and dimensions involved in its full implementation (De Young et al. 2008).

Despite highly optimistic claims by its proponents, we know of no cases where applying EBM has yielded its expected benefits. Implementing the FAO stock-specific "traffic-light" reference points approach to EAM will be problematic without proven, simple-to-measure EBM indicators (Caddy and Mahon 1995, Collie and Gislason 2001), a task more difficult than envisaged, especially in datapoor fisheries (Link 2005). Even in data-rich fisheries, complex multi-species interactions with multiple stakeholders in EBM (Leslie et al. 2008) can inadvertently heighten the exploitation of resources managed by multiple agencies with diffusely coordinated mandates. In Norway, EBM has even been used to argue for raising quotas for minke whales to offset their fish consumption (High North Alliance News 2004). If institutions can be designed flexibly to manage complex socialecological systems, incorporating broad yet effective participatory and inter-governmental decision-making strategies, EBM might lead to adaptive management that is robust in the face of scientific uncertainty (Francis et al. 2007, Hofmann and Gaines 2008, Levin and Lubchenco 2008, Palumbi et al. 2008). But, based on the practical framework of Ward et al. (2002), evaluation of the status of EBM implementation in the 33 top fishing nations revealed dismal results: no country scored a "good" grade, only four were within acceptable range, and 18 had "fail" grades (Pitcher et al. 2008). At its best, EBM does have the potential to succeed as a composite management strategy, if it incorporates some of the other policy instruments discussed here.

\section{Community-based management (CBM)}

Alternatively, devolving some government authority to civil society, "If only local communities (see Pinkerton and Weinstein 1995) and fishermen (Haggan et al. 2007) could co-manage (Jentoft 1989, Jentoft and McCay 1995, Wilson et al. 2003) their resources, then all will be well with fisheries." If local stakeholders and coastal communities participate or share authority in managing local resources, according to social scientists (Harris
1998, Jentoft 1998, Newell and Ommer 1999), there would be less overfishing by fishermen employing local ecological knowledge (LEK) in their harvesting strategies.

Co-management can empower local resource users and encourage conservation of the natural resources on which they depend for food and livelihood (Berkes 2004). Successful community-based management of fishery resources has evolved in Asia and the Pacific Islands (Ruddle 1998a,b,c, Johannes 2002, Ruddle and Segi 2006), Alaska (Kellert et al. 2000), British Columbia (Pinkerton $1999 a$ ), and the Maine lobster fishery (Acheson and Gardner 2005), but for a counterexample in Fiji, see Dulvy and Polunin (2004). If traditional socioeconomic systems governed by customary practices and laws (Trosper 2009) are allowed to determine fishery management plans and policies (Pinkerton 1999b), some of the environmental damage of large-scale, industrial, mixed-stock fisheries can be avoided. But local CBM lacks a global perspective and ecosystem-scale knowledge to set management and conservation goals (Weber and Iudicello 2005). Although the "rationale for community management is often compelling and convincing," in a lucid review of five community resource management schemes worldwide, Kellert et al. (2000) concluded that "serious deficiencies are widely evident." Community management does not necessarily produce its often-claimed benefits of more equitable distributions of power, economic returns, reduced conflict, use of traditional ecological knowledge, protection of biodiversity, food security, and sustainable use. In two North American examples (Kellert et al. 2000), key factors in achieving a higher level of success included: strong financial investment, robust local infrastructure, targeted public education, and strong legal support.

\section{Traditional ecological knowledge (TEK)}

An increasingly popular strategy, but fraught with cultural hurdles, is "If only we could incorporate traditional ecological knowledge (Kurien 1998, Berkes et al. 2000, Pierotti and Wildcat 2000, Folke 2004, Manseau et al. 2005, Menzies 2006, Berkes 2008) and indigenous peoples' cultural wisdom of the natural world (Snyder et al. 2003, Garabaldi and Turner 2004, Lam and Gonzalez-Plaza 2006), then all will be well with fisheries." A contribution in this Special Feature of Haida integrated marine planning (Jones et al. 2010) highlights British 
Columbia First Nations' perspectives on TEK in marine conservation (Drew 2005) and stewardship (Power and Chapin 2009). The benefits of incorporating TEK and LEK in fisheries management (Pierotti and Wildcat 1999, Haggan et al. 2007) and governance (Ruddle 1998b, Pinkerton $1999 a$, Jones 2000, Mackinson 2001, Johannes 2002) can be profound, but the more diverse and numerous the stakeholders, the more challenging and complex the management and governance (Pauly et al. 1998b). Lack of cross-cultural understanding often arises from differing cultural values of natural resources (Kirsch 2001, Lucas 2004), and cognitive models of nature can vary greatly with culture (Bang et al. 2007). Education in diverse ways of knowing may be one remedy, but is a slow process (Lam 2008). Although published persuasive examples of indigenous sustainable husbandry of resources are limited (e.g., Johnsen 2001, 2009, Deur and Turner 2005, Langdon 2007, Berkes 2008, Trosper 2009), they do challenge interpretations of archaeological evidence and analysis based on human foraging theory (Alvard 1993, Krech 2000, Alroy 2001, Ambrose 2001, Winterhalder and Smith 2002, Gillespie 2008).

\section{Historically based restoration}

In a simple sense, ecological restoration could also be characterized as a naturalistic fallacy: "If only we could go back to the way things were." But from a more realistic and complex perspective, this strategy is a composite of many of the previously discussed instruments. Lessons from history teach us that, rather than sustain fisheries, we have serially depleted, with ratchet-like increases in technological ingenuity, previously inaccessible resources (Pauly et al. 1998a, Pitcher 2001, Ainsworth et al. 2008b). Marine ecosystems have been fundamentally altered by overfishing, over millennia in some cases, and greatly accelerated in the past 50 years (Jackson et al. 2001, Pitcher 2001, Roberts 2007). Compelling evidence has been assembled from diverse locations and ecosystems (e.g., coral reefs: Pandolfi et al. 2003; large pelagic predatory fish: Myers and Worm 2003, but see Sibert et al. 2006; deep sea fisheries: Morato et al. 2006; seamounts: Pitcher et al. 2010). Informal data gathered from local fishermen typically support the contention that many fished ecosystems have been severely degraded (e.g., Sea of Cortez: Lozano-Montes et al. 2008, Saenz-Arroyo 2005a, $b$; Papua, Indonesia: Ainsworth et al. 2008a). Fishery managers often say that drastically altered systems, such as in Newfoundland, the Gulf of Thailand, or the South China Sea (Cheung and Pitcher 2008), are "still productive." Although this may be true in terms of fishery food products, degraded ecosystems comprise less valuable and desirable food species, are less biodiverse, and are less buffered against change. Ecosystems may unexpectedly become so degraded from fishing as to shunt energy into nonfish organisms (e.g., jellyfish and the "microbial loop"). And some ecosystems may never recover. We can avoid critical thresholds or "tipping points" (Marten 2005, Lenton et al. 2008, United Nations Environment Programme 2009) by first recognizing that ecosystems today are generally in degraded states compared with ancient ecosystems (Jackson and Hobbs 2009), and then proactively altering policy objectives.

To design an effective restoration strategy and policy goal, the history of a fishery must be understood (Costanza et al. 2007, Roberts 2007, Starkey et al. 2008). Reconstruction of past ecosystem states has been recognized in policy analyses as one hopeful way forward (e.g., in the United Kingdom, Royal Commission on Environmental Pollution 2004), a pragmatic but widely misunderstood restoration goal. Reconstruction of the past is confounded by local fish population extinctions, climate fluctuations, and human technological adaptations. Despite these considerable uncertainties, holistic ecosystem models, such as mass-balance and agent-based frameworks, can provide approximate quantitative snapshots of historical ecosystems. Figure 1 depicts this schematically for sample ecosystems, using archaeology, travellers' accounts, archival records, LEK and TEK, and scientific data, including rich information from DNA diversity analyses (see also Heymans and Pitcher 2004, Ainsworth et al. 2008a, c). "Back-to-the-Future" (Pitcher 2005) is a rigorous historical and holistic approach unlike other policy options: it is based on a profound historical and bioeconomic imperative for management. With a multi-disciplinary, semiquantitative ecosystem evaluation framework (Pitcher 2005), this policy tool for the restoration ecology of the oceans can characterize marine ecosystems and evaluate the status of threats to biodiversity, sustainability, and ecosystem functioning. It has led to a practical restoration agenda based on achievable EBM employing the concept of optimal restorable biomass (Pitcher 2008, Pitcher and 
Fig. 1. Holistic ecosystem models, such as mass-balance and agent-based frameworks, can provide approximate quantitative snapshots of historical ecosystems (triangles) and the biomass trajectories of organisms within them (boxes and arrows), based on archaeology, travellers' accounts, archival records, traditional (TEK) and local (LEK) ecological knowledge, and scientific data, including rich information from DNA diversity analyses.

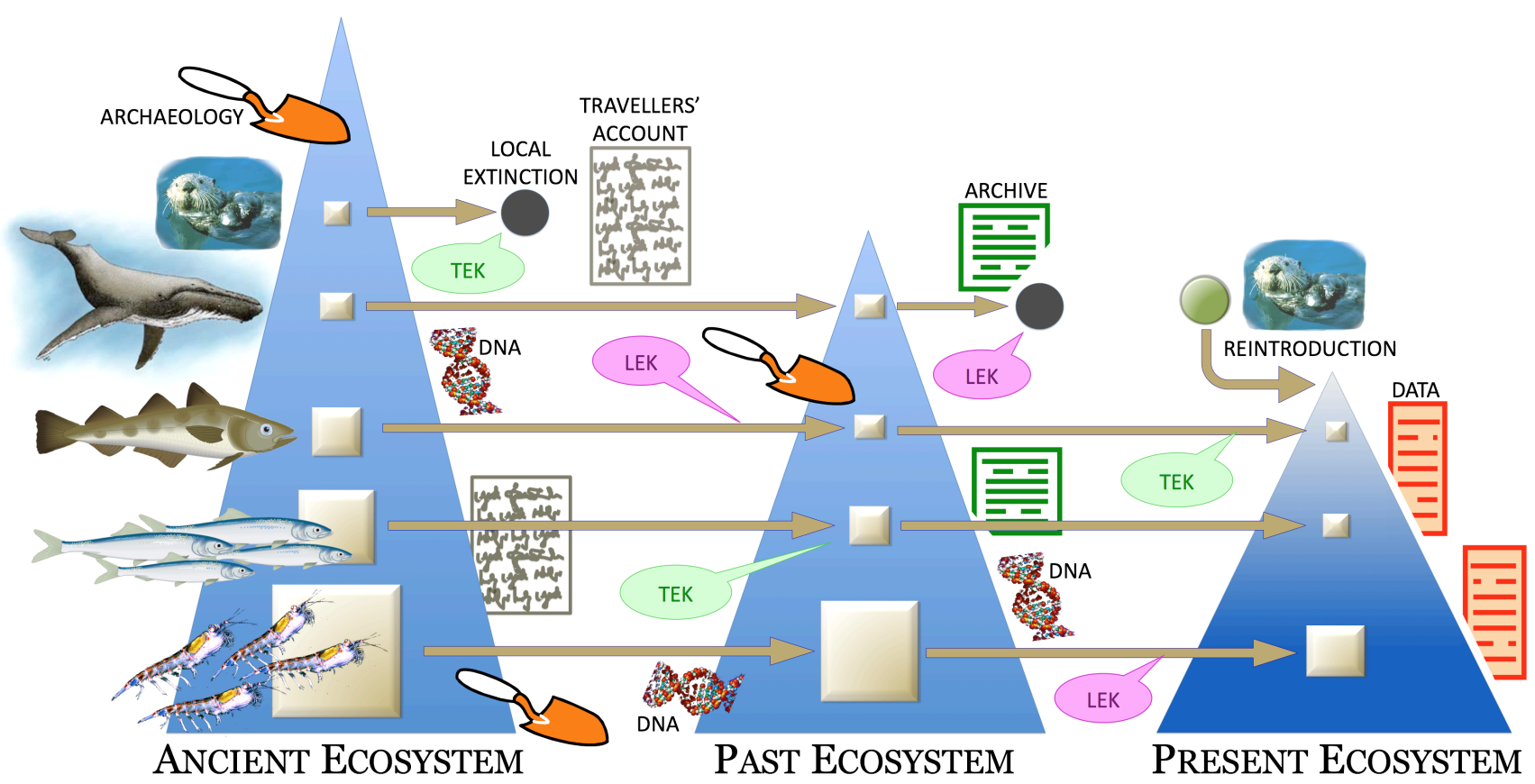

Ainsworth 2008). Fisher-led techniques in bycatch reduction may improve food security through a resilient fishing strategy "across the food web" (Pitcher and Ainsworth 2010). Management policy goals must aim to restore functioning, viable, and robust ecosystems and fish populations, not just sustain the biomass of depleted stocks (Pitcher and Pauly 1998). Historical reconstruction ("The Sea Before Us") and ecological restoration ("The Sea Ahead") are mandatory, in our view (Fig. 2), to rebuilding fisheries with bioeconomic and socially acceptable optima.

\section{DISCUSSION}

A fundamental flaw with all this "fishful thinking" is the widespread absence of well-defined, achievable targets for fisheries management. Longterm policy goals are an essential component of the
FAO's "Code of Conduct for Responsible Fisheries" (FAO 1995), a comprehensive but voluntary set of management rules that nations should address to sustain their fisheries. Compliance, unfortunately, is poor, as evaluated with a rapid appraisal technique ("Rapfish," Pitcher and Preikshot 2001). Most jurisdictions have not defined policy goals to track their progress in fisheries management: of 53 fishing nations (representing over 95\% of the world's catch), 18 failed completely, and only 24 scored "good" on this criterion (Pitcher et al. 2009a,b). Without specifying policy goals, any or all of the above fisheries management solutions, even if wellimplemented, will go awry. Policy goals are visions of what a society desires for its future; they must reflect two aspects of fisheries not yet discussed in the context of the ten management strategies above, namely ecological ethics and governance institutions. 
Fig. 2. Management policy goals today should aim to restore functioning, viable and robust future ecosystems (faint triangles), informed by historical reconstructions of ancient and past ecosystems (Figure 1), The Sea Before Us, to not deplete or merely sustain, but restore future fisheries, The Sea Ahead.

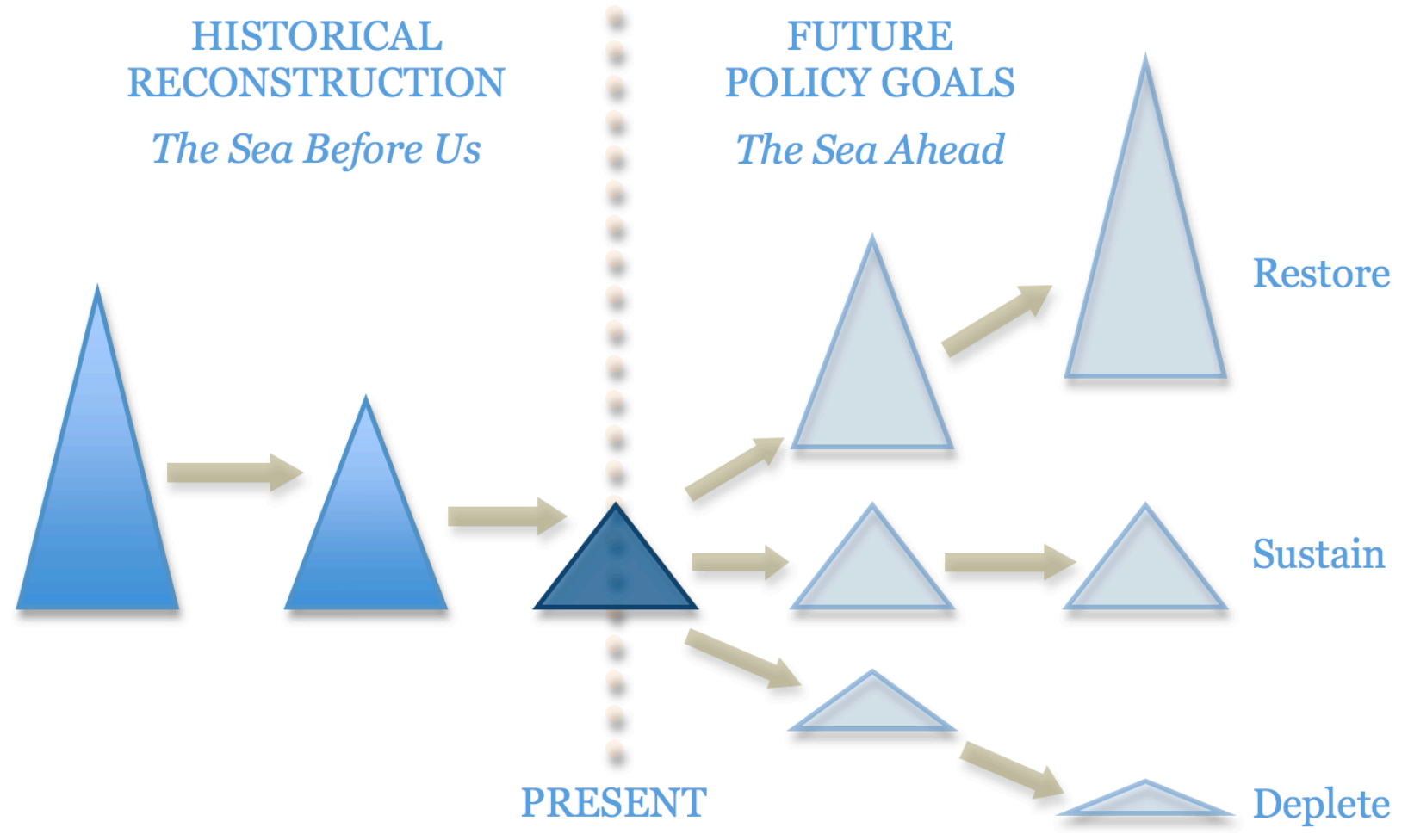

\section{Ecological ethics: trophic trade-offs and food security}

The urgent global need for human food may soon override any desire for sustainable management. Already, starvation is a reality in many parts of the developing world and the growing food shortage suggests a future in which demand for protein will only intensify. Many forecast a looming foodproduction gap as the human population escalates and major food-production processes become seriously constrained, both on land and in the sea. In fisheries, estimates of the gap between food demand and production range in the order of 30 million tonnes yearly of protein over the next 20 years (Delgado et al. 2003, FAO 2004). Whereas fishing down the trophic levels in marine food webs has been identified as a perverse symptom of overfishing, causing the serial depletion of predatory fish (Pauly et al. 1998a, Christensen et al. 2003), some have argued that we may have to do this deliberately to mitigate the problem of global hunger, especially amid concerns regarding the sustainability of terrestrial agriculture. Economic pressures and market values for increasingly scarce protein will surely exacerbate such tendencies. Intentionally fishing down the food web might well provide more food as biological production increases roughly ten-fold for each decrease in trophic level (Pauly and Christensen 1995).

Today's global fisheries operate at an average trophic level of about 3.3, so reducing this to 2.3 would theoretically increase the world's food harvest ten-fold. This prediction is an optimistic upper bound, however, as changes to food webs are 
unpredictable, and some organisms, known to bloom in trophic cascades (e.g., jellyfish and toxic phytoplankton), cannot be easily harvested or eaten by humans. More complex ecosystem analyses have estimated the amount of krill (planktonic euphausiids) that can be harvested sustainably from the world's oceans to provide easily assimilable protein for human consumption: e.g., using ecosystem modeling to minimize risks to biodiversity, trophic needs of krill predators, and sustainable benefits to existing fisheries, preliminary estimates suggest this precautionary krill harvest could give three times the protein of present fishery yields (Pitcher 2008). This raises an ethical question: under the exigencies of food security, would harvesting this planktonic resource, albeit in a precautionary manner, transform the privilege to fish into a basic human right to food?

Food-security issues have intensified where fisheries markets have opened up from global trade and industrial capacity. Forage fish, i.e., small and medium-sized pelagic fish eaten by larger fish, seabirds, and marine mammals, are increasingly caught for non-food purposes: as reduction to fishmeal, feed for poultry and carnivorous fish in aquaculture, and fish oil used in the food industry (Watson et al. 2006). As schooling fish, forage fish are easy to capture, requiring less fuel and reducing costs by nearly $40 \%$ (Watson et al. 2006). Their reduction to fishmeal and fish oil, however, has augmented market demand, causing prices to go up, just as their direct consumption for food has gone down (Alder et al. 2008); indeed, industrial uses of forage fish products compete with traditional human consumption of these lower trophic-level fish, especially in developing nations (Alder and Pauly 2006). Although Europeans may cope with eating less herring and sprats, Indonesians, Indians, and Africans suffer when sardines are turned into fishmeal for export, rather than marketed locally as food. This use of forage fish has thus become a privilege of the wealthy, over a right of the poor.

Pressure on forage and traditional fishes can easily compromise conservationist, not just human ethics. For example, in salmon aquaculture (Power 2008), the risk to wild salmon of farmed escapees and sea lice infestation aside, the ratio by weight of wild forage fish fed to farmed salmon produced is 3.16, whereas for the ten most commonly farmed types of fish and shell fish, this ratio ranges from 0.75 for carp to a staggering 5.16 for marine finfish (Naylor et al. 2000). Considerations of global food security should restrain this type of aquaculture, given the inefficiency of protein conversion from lowtrophic-level forage fish to high-trophic-level predatory fish, such as salmon, whose marine trophic level is analogous to that of lions in terrestrial webs (Morton and Volpe 2002). But the main consumers of farmed finfish live in affluent countries, who no longer have a taste for forage fish, whereas poor citizens in developing countries, having little influence on global markets, lose their forage fish to eat. The complex interplay between the ethical and ecological dimensions in fisheries is highlighted also in the destruction by fishermen, living in poverty and close to starvation, of many traditional fish stocks, including the "chambo" (a herbivorous pelagic tilapia), the national fish of Malawi. These stock depletions occurred despite management rights being devolved to local fishing communities in Lake Malawi and the Philippines (Pitcher 2006). Such overfishing is clearly unsustainable, as starving people forced to "eat the seed corn" are unable to discount their present food needs to save the fish for next year's bounty. With such dire circumstances increasingly common, fishing to eat "in extremis" must be viewed as a right, not a privilege.

Thus, the unavoidable ethical imperative for fishery scientists, from both the natural and social sciences (Ommer et al. 2008), is to find viable ways to mitigate such trophic trade-offs between immediate local food needs and long-term global food security: indeed, our simplistic dichotomy between the right and privilege to fish is not so much a choice as a trade-off between present and future valuing, with local and global impacts. The policy solutions to the global fisheries problem, contextualized to local needs, will require all of the complex tools of fisheries science described above. Options may entail steering both fishermen and consumers away from today's ecologically costly and heavily subsidized fishing practices to find other fish in the sea to fish and eat (Hall 2007, Halweil and Nierenberg 2008). Fishing lower down in the food web is an option that addresses both the privilege to fish for livelihood and the right to fish for food. A robust and quantitative evaluation of the trade-offs is needed to choose among complex policy options, if they are to be representative and transparent as policy goals themselves, rather than some accidental outcome (the world has had enough accidental outcomes in fisheries). With political will and societal awareness, fishing and eating lower down in the food web may become economically 
viable, ecologically sustainable, and socially just, both as a right and privilege.

\section{Governance institutions: managing people and fish}

Also missing in the simple solutions to fisheries management is adequate integration of the complex human dimension with the natural system (Berkes and Folke 1998, Carpenter and Gunderson 2001, Gunderson and Holling 2002, Berkes et al. 2003, Liu et al. 2007a,b, Garcia and Charles 2008). Fisheries management is widely acknowledged to be about managing humans, not fish (Ludwig et al. 1993, Pitcher et al. 1998, Hilborn 2007d), but the human dimensions of fisheries management (De Young et al. 2008) present formidable challenges. The interplay of diverse human interests, values, and preferences with respect to fishery resources (Lam and Sumaila 2008) is a global challenge that cannot be "solved" (Jentoft and Chuenpagdee 2009); it is instead exacerbated by an ever-growing, mobile, and technologically sophisticated human population competing for yet scarcer resources (Lam and Pauly, in press). Management of sustainable and responsible fisheries is both constrained and enabled by governance (Ostrom 1990, Kooiman 2003, Kooiman et al. 2005, Acheson 2006, Jentoft 2007, Agnew et al. 2009), that is, the "formal...mores which determine how resources or an environment are utilized" (Juda 1999: 90; see also Juda and Hennessey 2001). To sustain large marine ecosystems, an ecosystem approach must consider not only the natural system, via the productivity of the ecosystem, fish and fisheries, and pollution and ecosystem health, but also its human dimensions, namely the socioeconomic conditions and governance (Sherman 1995).

Research of social institutions needed for sustainable natural resource management (Ostrom 1990, 2007, 2009, Young 2002) and responsible fisheries governance (Sissenwine and Mace 2003) is clear: the fisheries problem can only be addressed with effective, incentive-based management instruments and a long-term, achievable policy goal. Understanding of sustainable fishery systems (Charles 2001) to design appropriate incentives and institutional structures to manage human behavior vis-à-vis fishery resources is emerging (e.g., Fujita et al. 1998, Hanna 1998, 2006, Hilborn et al. 2004, 2005a, Acheson 2006, Jentoft 2007, Grafton et al.
2007, De Young et al. 2008, Chuenpagdee and Jentoft 2009, Lam and Pauly 2010). Social incentives and governance institutions must be designed to account for not only economic sustainability of the fishing industry, but also ecological sustainability with appropriate conservation measures, while accounting for the conflicting interests and behaviors of resource users, managers, and politicians (Acheson 2006). Private incentives must be aligned along societal objectives, regulated and enforced to promote compliance by accounting for the scale and costs of fishery conservation (Wilson 2007) in management plans and policy goals. Despite this growing awareness of the complex human dimension in fisheries, ocean governance is in crisis, still marred by "conceptual confusion, spurious economics, and political indifference" (Bromley 2008: 7, 2009).

\section{CONCLUSIONS}

Transparent definition of achievable and restorative policy goals requires an evaluation framework that can assess singular and composite management strategies along multiple variables. Figure 3 displays the ten common management strategies, scored along five performance variables or modalities: ecological, economic and social viability, ethical status, and ease of institutional implementation. The pattern of scores, color coded for positive (green), neutral (gray), and negative (red) outcomes, provides a policy footprint for each management strategy. The "minimum" scores rate the weak or "panacea" scenarios, with performance assessed along each modality, then averaged; the "maximum" scores capture the nuances and enhancements of each management solution. The range between these two sets of scores expresses two sources of uncertainty, in our scoring and the outcomes of the strategy. Average scores estimate the aggregate performance of the management strategies across all modalities. Policy scores reflect our assessments based on the literature reviewed and combined experiences in, among other things, evaluating the quality of global fisheries management (Pitcher et al. 2009a,b, Mora et al. 2009) and designing a socioeconomic framework for fisheries valuation and analysis (Lam and Sumaila 2008). Clearly, objective criteria need to be standardized before the proposed policy 
Fig. 3. Composite policy performance ratings illustrating the trade-offs inherent in ten common fishery management strategies. The overall average performance of the management strategy rows increases from top to bottom; the numbers correspond to their order of discussion in the text. The pattern of scores, color-coded for positive (green, +1), neutral (grey, 0), and negative (red, -1) outcomes, provides a policy footprint for each strategy. Minimum and maximum scores were assigned by the authors for the weak 'panacea' and more nuanced descriptions, respectively, by synthesizing published accounts cited in the text and our individual experiences. The range between these scores expresses our estimate of the uncertainty in the strategy, while the average score is our best estimate for the performance of each management strategy, aggregated across all modalities. Columns correspond to assessments along five policy performance modalities: Ecological, Economic and Social scores are based on sustainability criteria that measure viability (Pitcher and Preikshot 2001); Ethical scores are informed by an interdisciplinary ethical analysis for fisheries (Pitcher and Power 2000; Coward et al. 2000); and Institutional scores relate to data and infrastructure required to implement an institutional framework (Ostrom 2005) capable of delivering this management strategy.

3. Laissez-faire

1. Privatization of Resources

5. Marine Protected Areas

6. Single-Species Stock Assessment

4. Selective Fishing Technology

8. Community-based Management

9. Traditional Ecological Knowledge

2. Total Economic Valuation

7. Ecosystem-based Management

10. Historically based Restoration
MINIMUM SCORE

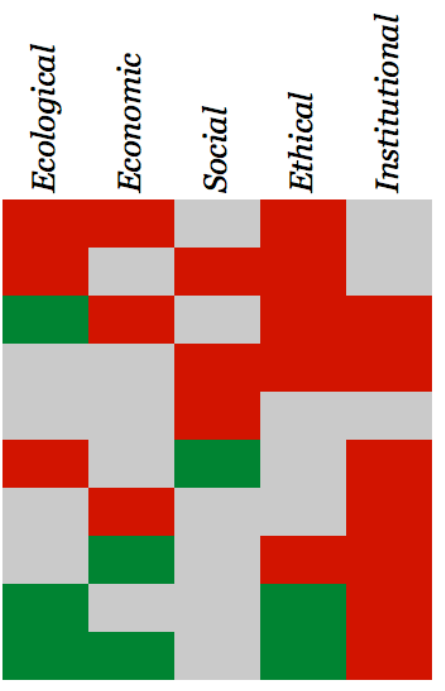

MAXIMUM SCORE

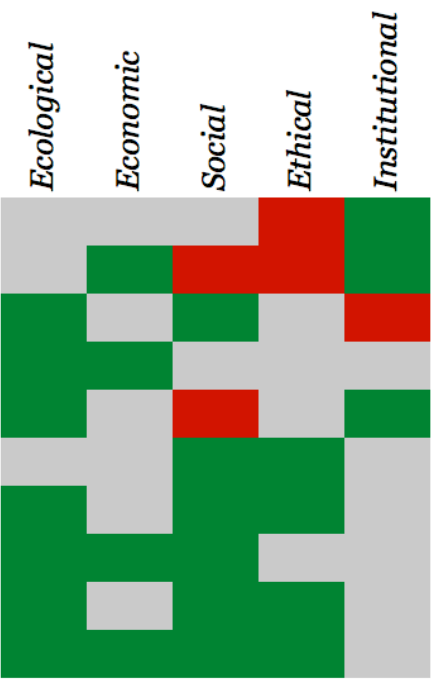

\begin{tabular}{|c|c|}
\hline 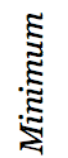 & 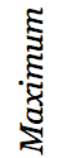 \\
\hline-0.6 & $O . O$ \\
\hline-0.6 & 0.0 \\
\hline-0.4 & 0.2 \\
\hline-0.6 & 0.4 \\
\hline-0.2 & 0.2 \\
\hline-0.2 & 0.4 \\
\hline-0.4 & 0.6 \\
\hline-0.2 & 0.6 \\
\hline o & 0.6 \\
\hline & 0.8 \\
\hline
\end{tabular}

evaluation framework can be rigorously applied, but Fig. 3 offers an informed methodological approach for making tough policy decisions by transparently conveying the perceived strengths and weaknesses of each management strategy. By our performance criteria and assessments, laissez-faire, privatization, MPAs, and conventional stock assessment are all, perhaps surprisingly to some, in the lower half of performance for the ten management strategies. The two best strategies, ecosystem-based management and historically based restoration, are inherently composite, being broad in space and deep in time, respectively, and thus better able to capture the complex human dimension of fisheries.
Aspects of all ten fisheries management strategies will likely need to be implemented, but none alone is sufficient to avert the growing global fisheries and looming food crises. The historical imperative tells us what happened in the past and helps us decide what we want for the future, by informing how we design socioeconomic incentives and policy goals today. Human demands and impacts on the sea are intensifying with global population growth, industrialization, and climate change. By examining historical ecosystems and customary practices and norms, by returning to traditional food sources and community-based management, by considering judicious use of plankton resources in an ecosystembased context, and by the selective and efficient use 
of technology, we may intentionally shift global society to a more desirable future. With scientific insight, powered by political will and consumer awareness, we can rebuild fisheries ethically, addressing the basic human right to food while leaving biodiverse marine ecosystems largely intact. "Fishful thinking" can easily degrade to "wishful fishing," but by widening our analytical nets, we can avoid getting caught by Hume's Guillotine and assess future trade-offs with composite fisheries management tools, effective institutions, and well-defined policy goals-and perhaps, even restore "fishful ecosystems."

Responses to this article can be read online at: http://www.ecologyandsociety.org/vol15/iss2/art12/ responses/

\section{Acknowledgments:}

The topic and approach of this manuscript reflect the original invitation to TJP to be a discussant in a symposium at the American Association for the Advancement of Science Annual Meeting in 2008 on The Privilege to Fish, co-organized by MEL and Meaghan Calcari. We thank the Gordon and Betty Moore Foundation for sponsorship of the symposium and this Special Feature, as well as the reviewers for useful suggestions.

\section{LITERATURE CITED}

Acheson, J. M. 2006. Institutional failure in resource management. Annual Review of Anthropology 35:117-134.

Acheson, J. M., and R. J. Gardner. 2005. Spatial strategies and territoriality in the Maine lobster industry. Rationality and Society 17(3):309-341.

Agardy, T. 2005. Global marine conservation policy versus site-level implementation: the mismatch of scale and its implications. Marine Ecology Progress Series 300:242-248.

Agardy, T., P. Bridgewater, M. P. Crosby, J. Day, P. K. Dayton, R. Kenchington, D. Laffoley, P. McConney, P. A. Murray, J. E. Parks, and L.
Peau. 2003. Dangerous targets? Unresolved issues and ideological clashes around marine protected areas. Aquatic Conservation: Marine and Freshwater Ecosystems 13(4):353-367.

Agnew, D. J., J. Pearce, G. Pramod, T. Peatman, R. Watson, J. R. Beddington, and T. J. Pitcher. 2009. Estimating the worldwide extent of illegal fishing. PLoS ONE 4(2):1-8.

Ainsworth, C. H., T. J., Pitcher, J. J. Heymans, and M. Vasconcellos. 2008a. Historical reconstruction of the marine ecosystem of northern British Columbia from pre-European contact to the present. Ecological Modelling 216:354-368.

Ainsworth, C. H., T. J. Pitcher, and C. Rotinsulu. $2008 b$. Evidence of fishery depletions and shifting cognitive baselines in eastern Indonesia. Biological Conservation 141(3):848-859.

Ainsworth, C. H., and U. R. Sumaila. 2005. Intergenerational valuation of fisheries resources can justify long-term conservation: a case study in Atlantic cod (Gadus morhua). Canadian Journal of Fisheries and Aquatic Sciences 62:1104-1110.

Ainsworth, C. H., D. A. Varkey, and T. J. Pitcher. 2008c. Ecosystem simulations supporting ecosystembased fisheries management in the Coral Triangle, Indonesia. Ecological Modelling 214(2-4):361374.

Alcock, F. 2002. Bargaining, uncertainty, and property rights in fisheries. World Politics $\mathbf{5 4}$ (4):437-461.

Alder, J., B. Campbell, V. Karpouzi, K. Kaschner, and D. Pauly. 2008. Forage fish: from ecosystems to markets. Annual Review of Environment and Resources 33:153-166.

Alder, J., and D. Pauly, editors. 2006. On multiple uses of forage fish: from ecosystems to markets. Fisheries Centre Research Reports. University of British Columbia, Fisheries Centre, Vancouver, British Columbia, Canada.

Allison, G. W., J. Lubchenco, and M. H. Carr. 1998. Marine reserves are necessary but not sufficient for marine conservation. Ecological Applications 8(1):S79-S92. 
Alroy, J. 2001. A multispecies overkill simulation of the end-Pleistocene megafaunal mass extinction. Science 292:1893-1896.

Alvard, M.S. 1993. Testing the "ecologically noble savage" hypothesis: interspecific prey choice by Piro hunters of Amazonian Peru. Human Ecology 21:355-387.

Ambrose, S. H. 2001. Paleolithic technology and human evolution. Science 291:1748-1753.

Arnason, R. 1998. Ecological fisheries management using individual transferable share quotas. Ecological Applications 8(1):S151-S159.

Bader, H. 1998. Who has the legal right to fish?: constitutional and common law in Alaska fisheries management. Marine Advisory Bulletin No. 49. University of Alaska Sea Grant College Program, Fairbanks, Alaska, USA.

Ballantine, W. J. 1997. "No-take" marine reserve networks support fisheries. Pages 702-706 in D. A. Hancock, D. C. Smith, A. Grant, and J. P. Beumer, editors. Developing and sustaining world fisheries resources: the state and management. Proceedings of the Second World Fisheries Congress, Brisbane, Australia, 1996. CSIRO Publishing, Collingwood, Australia.

Ballentine, W. J., and T. J. Langlois. 2008. Marine reserves: the need for systems. Hydrobiologia 606:35-44.

Bang, M., D. Medin, and S. Atran. 2007. Cultural mosaics and mental models of nature. Proceedings of the National Academy of Sciences 104:1386813874.

Beddington, J. R., D. J. Agnew, and C. W. Clark. 2007. Current problems in the management of marine fisheries. Science 316:1713-1716.

Berkes, F. 2004. Rethinking community-based conservation. Conservation Biology 18:621-630.

Berkes, F. 2008. Sacred ecology: traditional ecological knowledge and resource management. Second edition, Routledge, London, UK.

Berkes, F., J. Colding, and C. Folke, editors. 2003. Navigating social-ecological systems. Cambridge University Press, Cambridge, UK.
Berkes, F., J. Colding, and C. Folke, editors. 2000. Rediscovery of traditional ecological knowledge as adaptive management. Ecological Applications 10(5):1251-1262.

Berkes, F., and C. Folke, editors. 1998. Linking social and ecological systems. Cambridge University Press, Cambridge, UK.

Berkes, F., T. P. Hughes, R. S. Steneck, J. A. Wilson, D. R. Bellwood, B. Crona, C. Folke, L. H. Gunderson, H. M. Leslie, J. Norberg, M. Nyström, P. Olsson, H. Österblom, M. Scheffer, and B. Worm. 2006. Policy forum ecology: globalization, roving bandits, and marine resources. Science 311:1557-1558.

Beverton, R. J. H., and S. J. Holt. 1957. On the dynamics of exploited fish populations. Fishery Investigations Series II, Volume XIX, Ministry of Agriculture, Fisheries and Food, Great Britain.

Bohnsack, J. A., J. S. Ault, and B. Causey. 2004. Why have no-take marine protected areas? Pages 185-193 in J. B. Shipley, editor. Aquatic protected areas as fisheries management tools. American Fisheries Society, Symposium 42, Bethesda, Maryland, USA.

Branch, T. A. 2009. How do individual transferable quotas affect marine ecosystems? Fish and Fisheries 10(1):39-57.

Branch, T., R. Hilborn, A. C. Haynie, G. Fay, L. Flynn, J. Griffiths, K. N. Marshall, J. K. Randall, J. M. Scheuerell, E. J. Ward, and M. Young. 2006. Fleet dynamics and fishermen behavior: lessons for fisheries managers. Canadian Journal of Fisheries and Aquatic Sciences 63:1647-1668.

Bromley, D. W. 2005. Purging the frontier from our mind: crafting a new fisheries policy. Reviews in Fish Biology and Fisheries 15:217-229.

Bromley, D. W. 2008. The crisis in ocean governance: conceptual confusion, spurious economics, political indifference. MAST 6(2):7-22.

Bromley, D. W. 2009. Abdicating responsibility: the deceits of fisheries policy. Fisheries 34(6): 280 290.

Browman, H. I., and K. I. Stergiou, editors. 2004. Perspectives on ecosystem-based approaches to the 
management of marine resources. Marine Ecology Progress Series 274:269-303.

Browman, H. I., and K. I. Stergiou, editors. 2005. Politics and socio-economics of ecosystem-based management of marine resources. Marine Ecology Progress Series 300:241-296.

Brown, T. C., J. C. Bergstrom, and J. B. Loomis. 2007. Defining, valuing, and providing ecosystem goods and services. Natural Resources Journal 47:329-375.

Caddy, J. F., and R. Mahon. 1995. Reference points for fisheries management. Food and Agriculture Organization (FAO) Fisheries Technical Paper 347. FAO, Rome, Italy.

Caddy, J. F., and J. C. Seijo. 2005. This is more difficult than we thought! The responsibility of scientists, managers and stakeholders to mitigate the unsustainability of marine fisheries. Philosophical Transactions of the Royal Society B 360(1453):5975.

Carpenter, S. R., and L. H. Gunderson. 2001. Coping with collapse: ecological and social dynamics in ecosystem management. BioScience 51 (6):451-457.

Castilla, J. C., S. Gelcich, and O. Defeo. 2007. Successes, lessons, and projections from experience in marine benthic invertebrate artisanal fisheries in Chile. Chapter 2 in T. McClanahan and J. C. Carlos, editors. Fisheries management: progress towards sustainability. Wiley-Blackwell, Oxford, UK.

Charles, A. T. 2001. Sustainable fishery systems. Blackwell Science, Oxford, UK.

Cheung, W. W. L., and T. J. Pitcher. 2008. Evaluating the status of exploited taxa in the northern South China Sea using intrinsic vulnerability and spatially explicit catch-per-uniteffort data. Fisheries Research 92:28-40.

Christensen, V., S. Guénette, J. J. Heymans, C. J. Walters, R.. Watson, D. Zeller, and D. Pauly. 2003. Hundred-year decline of North Atlantic predatory fishes. Fish and Fisheries 4:1-24.

Christy, F. T. 1997. The death rattle of open access and the advent of property rights regimes in fisheries. Marine Resource Economics 11:287-304.
Chu, C. 2008. Thirty years later: the global growth of ITQs and their influence on stock status in marine fisheries. Fish and Fisheries 10:1-14.

Chuenpagdee, R., and S. Jentoft. 2009. Governability assessment for fisheries and coastal systems: a reality check. Human Ecology 37:109_ 120.

Clark, C. W. 1973. The economics of overexploitation. Science 181(4100):630-634.

Clark, C. W., G. R. Munro, and U. R. Sumaila. 2005. Subsidies, buybacks, and sustainable fisheries. Journal of Environmental Economics and Management 50:47-58.

Clark, C. W., G. R. Munro, and U. R. Sumaila. 2010. Limits to the privatization of fishery resources. Land Economics 86(2):209-218.

Coastal Communities News. 2002. Fisheries that work: exploring the alternatives to individual transferable quotas. Coastal Communities Network, Pictou, Nova Scotia, Canada.

Collie, J., and H. Gislason. 2001. Biological reference points for fish stocks in a multispecies context. Canadian Journal of Fisheries and Aquatic Sciences 58:2167-2176.

Costanza, R., L. Graumlich, W. Steffen, C. Crumley, J. Dearing, K. Hibbard, R. Leemans, C. Redman, and D. Schimel. 2007. Sustainability or collapse: what can we learn from integrating the history of humans and the rest of nature? Ambio 36 (7):522-527.

Costanza, R., R. d'Arge, R. de Groot, S. Farber, M. Grasso, B. Hannon, K. Limburg, S. Naeem, R. V. O'Neill, J. Paruelo, R. G. Raskin, P. Sutton, and M. van den Belt. 1997. The value of the world's ecosystem services and natural capital. Nature 387:253-260.

Costello, C., S. D. Gaines, J. Lynham. 2008. Can catch shares prevent fisheries collapses? Science 321:1678-1681.

Coward, H., R. Ommer, and T. J. Pitcher, editors. 2000. Just fish: ethics and Canadian marine fisheries. Social and Economic Papers No. 23, Institute of Social and Economic Research, Memorial University of Newfoundland, St. John's, Newfoundland and Labrador, Canada. 
Crowder, L. B., G. Osherenko, O. R. Young, S. Airamé, E. A. Norse, N. Baron, J. C. Day, F. Douvere, C. N. Ehler, B. S. Halpern, S. J. Langdon, K. L. McLeod, J. C. Ogden, R. E. Peach, A. A. Rosenberg, and J. A. Wilson. 2006. Policy forum sustainability: resolving mismatches in U.S. ocean governance. Science 313(5786): 617618.

Daily, G. C., S. Alexander, P. R. Ehrlich, L. Goulder, J. Lubchenco, P. A. Matson, H. A. Mooney, S. Postel, S. H. Schneider, D. Tilman, and G. M. Woodwell. 1997. Ecosystem services: benefits supplied to human societies by natural ecosystems. Issues in Ecology 2. Ecological Society of America, Washington, D.C., USA.

Dalton, R. 2005. Conservation policy: fishy futures. Nature 437:473-474.

Dalton, R. 2006. Fish futures. Conservation in practice 7(3):23-34.

Dasgupta, P., and K.-G. Mäler. 2004. Environmental and resource economics: some recent developments. South Asian Network for Development and Environmental Economics (SANDEE) Working Paper No. 7 - 04, Kathmandu, Nepal.

Degnbol, P., H. Gislason, S. Hanna, S. Jentoft, J. R. Nielsen, S. Sverdrup-Jensen, and D. C. Wilson. 2006. Painting the floor with a hammer: technical fixes in fisheries management. Marine Policy 30:534-543.

Delgado, C. L., N. Wada, M. W. Rosegrant, S. Meijer, and M.Ahmed. 2003. Fish to 2020: supply and demand in changing global markets. International Food Policy Research Institute (IFPRI), Washington, D.C., USA.

Deur, D., and N. J. Turner, editors. 2005. Keeping it living: traditions of plant use and cultivation on the northwest coast of North America. University of Washington Press/UBC Press, Seattle, Washington, USA and Vancouver, British Columbia, Canada.

De Young, C., A. Charles, and A. Hjort. 2008. Human dimensions of the ecosystem approach to fisheries: an overview of context, concepts, tools and methods. Food and Agriculture Organization of the United Nations (FAO) Fisheries Technical Paper No. 489. FAO, Rome, Italy.

Drew, J. A. 2005. Use of traditional ecological knowledge in marine conservation. Conservation Biology 19:1286-1293.

Dulvy, N. K., and N. V. C. Polunin. 2004. Using informal knowledge to infer human-induced rarity of a conspicuous reef fish. Animal Conservation 7:365-374.

Essington, T. E., A. H. Beaudreau, and J. Wiedenmann. 2006. Fishing through marine food webs. Proceedings of the National Academy of Sciences 103(9):3171-3175.

Eythórsson, E. W. 2000. A decade of ITQmanagement in Icelandic fisheries: consolidation without consensus. Marine Policy 24:483-492.

Folke, C. 2004. Traditional knowledge in socialecological systems. Ecology and Society 9(3):7. [online] URL: http://www.ecologyandsociety.org/vol9/ iss3/art7/.

Food and Agriculture Organization of the United Nations (FAO). 1995. Code of Conduct for Responsible Fisheries. FAO, Rome, Italy. [online] URL: ftp://ftp.fao.org/docrep/fao/005/v9878e/v9878e00. pdf.

Food and Agriculture Organization of the United Nations (FAO). 2003a. Towards ecosystem-based fisheries management. Pages 393-403 in $\mathrm{M}$. Sinclair and G. Valdimarsson, editors. Responsible fisheries in marine ecosystems. FAO, Rome, Italy.

Food and Agriculture Organization of the United Nations (FAO). 2003b. Report of the twenty-fifth session of the Committee on Fisheries. FAO Fisheries Report 702, FAO, Rome, Italy.

Food and Agriculture Organization of the United Nations (FAO). 2004. Future prospects for fish and fishery products: medium-term projections to the years 2010 and 2015. Fisheries Circular FIDI/972-1. FAO, Rome, Italy.

Forrest, R. E., S. J. D. Martell, M. C. Melnychuk, and C. J. Walters. 2008. An age-structured model 
with leading management parameters, incorporating age-specific selectivity and maturity. Canadian Journal of Fisheries and Aquatic Sciences 65:286296.

Francis, R. C., M. A. Hixon, S. A. Murawski, S. Ralston. 2007. Ten commandments for ecosystembased fisheries scientists. Fisheries 32(5):217-233.

Fujita, R., and K. Bonzon. 2005. Rights-based fisheries management: an environmentalist perspective. Reviews in Fish Biology and Fisheries 15:309-312.

Fujita, R. M., T. Foran, and I. Zevos. 1998. Innovative approaches for fostering conservation in marine fisheries. Ecological Applications 8(1): S139-S150.

Garcia, S. M., and A. T. Charles. 2008. Fishery systems and linkages: implications for science and governance. Ocean and Coastal Management 51:505-527.

Garibaldi, A., and N. Turner. 2004. The nature of culture and keystones. Ecology and Society 9(3):r2. [online] URL: http://www.ecologyandsociety.org/vol9/ iss3/resp2/.

Gell, F. R., and C. M. Roberts. 2003. Benefits beyond boundaries: the fishery effects of marine reserves. Trends in Ecology and Evolution 18 (9):448-455.

Gibbs, M. T. 2009. Individual transferable quotas and ecosystem-based fisheries management: it's all in the T. Fish and Fisheries 10:470-474.

Gillespie, R. 2008. Updating Martin's global extinction model. Quaternary Science Reviews 27 (27-28):2522-2529.

Grafton, R. Q. 1996. Individual transferable quotas: theory and practice. Reviews in Fish Biology and Fisheries 6:5-20.

Grafton, R. Q., R. Arnason, T. Bjørndal, D. Campbell, H. F. Campbell, C. W. Clark, R. Connor, D. P. Dupont, R. Hannesson, R. Hilborn, J. E. Kirkley, T. Kompas, D. E. Lane, G. R. Munro, S. Pascoe, D. Squires, S. I. Steinshamn, B. R. Turris, and Q. Weninger. 2006. Perspective: incentive-based approaches to sustainable fisheries. Canadian Journal of Fisheries and Aquatic Sciences 63:699-710.
Grafton, R. Q., T. Kompas, R. McLoughlin, N. Rayns. 2007. Benchmarking for fisheries governance. Marine Policy 31:470-479.

Grumbine, R. E. 1994. What is ecosystem management? Conservation Biology 8(1):27-38.

Grumbine, R. E. 1997. Reflections on "what is ecosystem management?" Conservation Biology 11 (1):41-47.

Guénette, S., R. Chuenpagdee, and R. Jones. 2000. Marine protected areas with an emphasis on local communities and indigenous peoples: a review. Fisheries Centre Research Reports 8(1). University of British Columbia, Fisheries Centre, Vancouver, British Columbia, Canada.

Guénette, S., T. Lauck, and C. Clark. 1998. Marine reserves: from Beverton and Holt to the present. Reviews in Fish Biology and Fisheries 8:251-272.

Gunderson, L. H., and C. S. Holling, editors. 2002. Panarchy: understanding transformations in human and natural systems. Island Press, Washington, D.C., USA.

Haggan, N., B. Neis, and I. G. Baird, editors. 2007. Fishers' knowledge in fisheries science and management. Coastal Management Sourcebooks 4, UNESCO Publishing, Paris, France.

Hall, M. 2007. Eat more anchovies. Page 24 in S. Simpson, editor. 10 solutions to save the ocean. Conservation 8(3):23-32.

Halweil, B., and D. Nierenberg. 2008. Meat and seafood: the global diet's most costly ingredients. Pages 61-74 in State of the world 2008: innovations for a sustainable economy. The Worldwatch Institute, Washington, D.C., USA.

Hanna, S. S. 1998. Institutions for marine ecosystems: economic incentives and fishery management. Ecological Applications 8(1):S170S174.

Hanna, S. S. 2006. Implementing effective regional ocean governance: perspectives from economics. Duke Environmental Law and Policy Forum 16:205-216. 
Hannesson, R. 1998. The role of economic tools in redefining fisheries management. Pages 251-260 in T. J. Pitcher, P. J. B. Hart, and D. Pauly, editors. Reinventing fisheries management. Kluwer Academic Publishers, Dordrecht, The Netherlands.

Hannesson, R. 2005. Rights based fishing: use rights versus property rights to fish. Reviews in Fish Biology and Fisheries 15:231-241.

Harris, C. K. 1998. Social regime formation and community participation in fisheries management. Pages 261-276 in T. J. Pitcher, P. J. B. Hart, and D. Pauly, editors. Reinventing fisheries management. Kluwer Academic Publishers, Dordrecht, The Netherlands.

Harris, D. C. 2001. Fish, law, and colonialism: the legal capture of salmon in British Columbia. University of Toronto Press, Toronto, Ontario, Canada.

Heymans, J. J., and T. J. Pitcher. 2004. Synoptic methods for constructing models of the past. Pages 11-17 in T. J. Pitcher, editor. Back to the future: advances in methodology for modelling and evaluating past ecosystems as future policy goals. Fisheries Centre Research Reports 12(1):1-158.

High North Alliance News. 2004. Norway's Parliament instructs government to substantially increase whaling quota as soon as possible. [online] URL: http://www.highnorth.no/news/nedit.asp? which $=321$.

Hilborn, R. 2007a. Defining success in fisheries and conflicts in objectives. Marine Policy 31:153158 .

Hilborn, R. 2007b. Managing fisheries is managing people: what has been learned? Fish and Fisheries 8(4):285-296.

Hilborn, R. 2007c. Moving to sustainability by learning from successful fisheries. Ambio 36:296303.

Hilborn, R. 2007d. Reinterpreting the state of fisheries and their management. Ecosystems $\mathbf{1 0}$ (8):1362-1369.

Hilborn, R., T. A. Branch, B. Ernst, A. Magnusson, C. V. Minte-Vera, M. D. Scheuerell, and J. L. Valero. 2003. State of the world's fisheries. Annual Review of Environment and Resources 28:359-399.

Hilborn, R., J. M. (L.) Orensanz, and A. M. Parma. 2005a. Institutions, incentives and the future of fisheries. Philosophical Transactions of the Royal Society B 360:47-57.

Hilborn, R., J. K. Parrish, and K. Litle. $2005 b$. Fishing rights or fishing wrongs? Reviews in Fish Biology and Fisheries 15:191-199.

Hilborn, R., A. E. Punt, and J. Orensanz. 2004. Beyond band-aids in fisheries management: fixing world fisheries. Bulletin of Marine Science $\mathbf{7 4}$ (3):493-507.

Hofmann, G. E., and S. D. Gaines. 2008. New tools to meet new challenges: emerging technologies for managing marine ecosystems for resilience. BioScience 58(1):43-52.

Hume, D. 1740. A treatise of human nature. [online] URL: http://www.gutenberg.org/dirs/etext03/trthn10. $\underline{\text { txt. }}$

Jackson, J. B. C., M. X. Kirby, W. H. Berger, K. A. Bjorndal, L. W. Botsford, B. J. Bourque, R. Bradbury, R. Cooke, J. Erlandson, J. A. Estes, T. P. Hughes, S. Kidwell, C. B. Lange, H.S. Lenihan, J. M. Pandolfi, C. H. Peterson, R. S. Steneck, M. J. Tegner, and R. R. Warner. 2001. Historical overfishing and the recent collapse of coastal ecosystems. Science 293(5530):629-638.

Jackson, S. T., and R. J. Hobbes. 2009. Ecological restoration in the light of ecological history. Science 325:567-568.

Jennings, F. B. 1999. Individual transferable quotas (ITQs) and a 'systems analysis' of their likely effects. Center for Ecological Economic and Ethical Education, Ipswich, Massachusetts, USA.

Jennings, F. B. 2007. The design of free-market economies in a post-neoclassical world. Center for Ecological Economic and Ethical Education, Ipswich, Massachusetts, USA.

Jentoft, S. 1989. Fisheries co-management: delegating government responsibility to fishermen's organizations. Marine Policy 13(2):137-154. 
Jentoft, S. 1998. Social science in fisheries management: a risk assessment. Pages 177-184 in T. J. Pitcher, P. J. B. Hart, and D. Pauly, editors. Reinventing fisheries management. Kluwer Academic Publishers, Dordrecht, The Netherlands.

Jentoft, S. 2007. Limits of governability: institutional implications for fisheries and coastal governance. Marine Policy 31:360-370.

Jentoft, S., and R. Chuenpagdee. 2009. Fisheries and coastal governance as a wicked problem. Marine Policy 33:553-560.

Jentoft, S., and B. McCay. 1995. User participation in fisheries management: lessons drawn from international experiences. Marine Policy 19 (3):227-246.

Johannes, R. E. 2002. The renaissance of community-based marine resource management in Oceania. Annual Review of Ecology and Systematics 33:317-340.

Johnsen, D. B. 2001. Customary law, scientific knowledge, and fisheries management among northwest coast tribes. Environmental Law Journal 10(1):1-69.

Johnsen, D. B. 2009. Salmon, science, and reciprocity on the Northwest Coast. Ecology and Society 14(2): 43. [online] URL: http://www.ecolog yandsociety.org/vol14/iss2/art43.

Jones, P. J. S. 2002. Marine protected area strategies: issues, divergences and the search for middle ground. Reviews in Fish Biology and Fisheries 11:197-216.

Jones, P. J. S. 2007. Point-of-view: arguments for conventional fisheries management and against notake marine protected areas: only half of the story? Reviews in Fish Biology and Fisheries 17(1):31-43.

Jones, R. 2000. The herring fishery of Haida Gwaii: an ethical analysis. Pages 201-224 in H. Coward, R. Ommer, and T. Pitcher, editors. Just fish: ethics and Canadian marine fisheries. Social and Economic Papers No. 23, Institute of Social and Economic Research, Memorial University of Newfoundland, St. John's, Newfoundland and Labrador, Canada.
Jones, R., C. Rigg, and L. Lee. 2010. Haida marine planning: First Nations as a partner in marine conservation. Ecology and Society 15(1): 12. [online] URL: http://www.ecologyandsociety.org/vol15/ iss1/art12.

Juda, L. 1999. Considerations in developing a functional approach to the governance of large marine ecosystems. Ocean Development and International Law 30:89-125.

Juda, L., and T. Hennessey. 2001. Governance profiles and the management of the uses of large marine ecosystems. Ocean Development and International Law 32:43-69.

Kellert, S. R., J. Mehta, S. A. Ebbin, and L. Lichtenfeld. 2000. Community natural resource management: promise, rhetoric, and reality. Society and Natural Resources 13:705-715.

Kennelly, S. J., editor. 2007. By-catch reduction in the world's fisheries. SpringerLink, Berlin, Germany.

Kennelly, S. J., and M. K. Broadhurst. 2002. Bycatch begone: changes in the philosophy of fishing technology. Fish and Fisheries 3:340-355.

Kirsch, S. 2001. Lost worlds: environmental disaster, "culture loss", and the law. Current Anthropology 42(2):167-178.

Kooiman, J. 2003. Governing as governance. Sage Publications, London, UK.

Kooiman, J., M. Bavinck, S. Jentoft, and R. Pullin, editors. 2005. Fish for life: interactive governance for fisheries. Amsterdam University Press, Amsterdam, The Netherlands.

Krech, S. III. 2000. The ecological Indian: myth and history. W. W. Norton \& Company, New York, New York, USA.

Kurien, J. 1998. Traditional ecological knowledge and ecosystem sustainability: new meaning to Asian coastal proverbs. Ecological Applications 8(1):S2 S5.

Lam, M. E. 2008. Valuing diverse ways of knowing. Winds of Change: American Indian Education and Opportunity 23(3):42-46. 
Lam, M. E., and R. Gonzalez-Plaza. 2006. Evolutionary universal aesthetics in ecological rationality. Journal of Ecological Anthropology. 10 (1):66-71.

Lam, M. E., and D. Pauly. 2010. Who's right to fish? Evolving a new social contract for ethical fisheries. Ecology and Society, in press.

Lam, M. E., and U. R. Sumaila. 2008. Socioeconomics discussion paper: proposed revised multiple accounts evaluation framework emphasizing sociological resilience and community profile indicators. Fisheries and Oceans Canada, Ottawa, Ontario, Canada.

Langdon, S. J. 2007. Sustaining a relationship: inquiry into the emergence of a logic of engagement with salmon among the southern Tlingits. Pages 233-373 in M. E. Harkin and D. R. Lewis. Native Americans and the environment: perspectives on the ecological Indian. University of Nebraska Press, Lincoln, Nebraska, USA.

Larkin, P. A. 1996. Concepts and issues in marine ecosystem management. Reviews in Fish Biology and Fisheries 6:139-164.

Lauck, T., C. W. Clark, M. Mangel, and G. R. Munro. 1998. Implementing the precautionary principle in fisheries management through marine reserves. Ecological Applications 8(1):S72-S78.

Lenton, T. M., H. Held, E. Kriegler, J. W. Hall, W. Lucht, S. Rahmstorf, and H. J. Schellnhuber. 2008. Tipping elements in the Earth's climate system. Proceedings of the National Academy of Sciences 105(6):1786-1793.

Leslie, H., A. A. Rosenberg, and J. Eagle. 2008. Two views: is a new mandate needed for marine ecosystem-based management? Frontiers in Ecology and the Environment 6:43-48.

Levin, S. A., S. Barrett, S. Aniyar, W. Baumol, C. Bliss, B. Bolin, P. Dasgupta, P. Ehrlich, C. Folke, I.-M. Gren, C. S. Holling, A. Jansson, B.-O. Jansson, K.-G. Mäler, D. Martin, C. Perrings, and E. Sheshinski. 1998. Resilience in natural and socioeconomic systems. Environment and Development Economics 3:222-235.
Levin, S. A., and J. Lubchenco. 2008. Resilience, robustness, and marine ecosystem-based management. BioScience 58(1):27-32.

Libecap, G. D. 2008. Open-access losses and delay in the assignment of property rights. Arizona Law Review 50(2):379-408.

Link, J. 2005. Translating ecosystem indicators into decision criteria. ICES Journal of Marine Science 62:569-576.

Liu, J., T. Dietz, S. R. Carpenter, M. Alberti, C. Folke, E. Moran, A. N. Pell, P. Deadman, T. Kratz, J. Lubchenco, E. Ostrom, Z. Ouyang, W. Provencher, C. L. Redman, S. H. Schneider, and W. W. Taylor. 2007a. Complexity of coupled human and natural systems. Science 317:1513-1516.

Liu, J., T. Dietz, S. R Carpenter, C. Folke, M. Alberti, C. L. Redman, S. H. Schneider, E. Ostrom, A. N. Pell, J. Lubchenco, W. W. Taylor, Z. Ouyang, P. Deadman, T. Kratz, and W. Provencher. 2007b. Coupled human and natural systems. Ambio 36(8):639-649.

Lozano-Montes, H., T. J. Pitcher, and N. Haggan. 2008. Shifting environmental and cognitive baselines in the upper Gulf of California (Mexico): local fisher's knowledge reveals a slow-motion disaster. Frontiers in Ecology and the Environment 6(2):75-80.

Lubchenco, J., S. R. Palumbi, S. D. Gaines, and S. Andelman. 2003. Plugging a hole in the ocean: the emerging science of marine reserves. Ecological Applications 13(1):S3-S7.

Lucas, S. 2004. Aboriginal values. Pages 114-116 in T. J. Pitcher, editor. Back to the future: advances in methodology for modelling and evaluating past ecosystems as future policy goals. Fisheries Centre Research Reports. University of British Columbia, Fisheries Centre, Vancouver, British Columbia, Canada.

Ludwig, D., R. Hilborn, and C. Walters. 1993. Uncertainty, resource exploitation, and conservation: lessons from history. Science 260:17-18.

Mace, P. M. 2001. A new role for MSY in singlespecies and ecosystem approaches to fisheries stock 
assessment and management. Fish and Fisheries 2:2-32.

Macinko, S., and D. W. Bromley. 2002. Who owns America's fisheries? Island Press, Washington, D. C., USA.

Macinko, S., and D. W. Bromley. 2004. Property and fisheries for the twenty-first century: seeking coherence from legal and economic doctrine. Vermont Law Review 28:623-661.

Mackinson, S. 2001. Integrating local and scientific knowledge: an example in fisheries science. Environmental Management 27(4):533-545.

Maguire, J.-J., B. Neis, and P. R. Sinclair. 1995. What are we managing anyway?: the need for an interdisciplinary approach to managing fisheries ecosystems. Dalhousie Law Journal 18:141-153.

Mangel, M., L. M. Talbot, G. K. Meffe, M. Tundi, T. Agardy, D. L. Alverson, J. Barlow, D. B. Botkin, G. Budowski, T. Clark, J. Cooke, R. H. Crozier, P. K. Dayton, D. L. Elder, C. W. Fowler, S. Funtowicz, J. Giske, D. Ludwig, K. Magnusson, B. S. Malayang, III, C. Mann, E. A. Norse, S. P. Northridge, W. F. Perrin, C. Perrings, R. M. Peterman, G. B. Rabb, H. A. Regier, J. E. Reynolds, III, K. Sherman, M. P. Sissenwine, T. D. Smith, A. Starfield, R. J. Taylor, M. F. Tillman, C. Toft, J. R. Twiss, Jr., J. Wilen, and T. P. Young. 1996. Principles for the conservation of wild living resources. Ecological Applications 6(2):338-362.

Manseau, M., B. Parlee, and G. B. Ayles. 2005. A place for traditional ecological knowledge in resource management. Pages 141-164 in F. Berkes, R. Huebert, H. Fast, M. Manseau, and A. Diduck, editors. Breaking ice: renewable resource and ocean management in the Canadian North. University of Calgary Press, Calgary, Alberta, Canada.

Martell, S. J., C. Walters, and U. R. Sumaila. 2008. Industry-funded fishing license reduction good for both profits and conservation. Fish and Fisheries 9:1-12.

Marten, G. G. 2005. Environmental tipping points: a new paradigm for restoring ecological security. Journal of Policy Studies (Japan) 20:75-87.
Mascia, M. B. 2003. The human dimension of coral reef marine protected areas: recent social science research and its policy implications. Conservation Biology 17(2):630-632.

Matthews, D. R. 1995. Commons versus open access: the collapse of Canada's east coast fishery. The Ecologist 25:86-104.

May, R. M., S. A. Levin, and G. Sugihara. 2008. Ecology for bankers. Nature 451:893-895.

McCay, B. J., and A. C. Finlayson. 1995. The political ecology of crisis and institutional change: the case of the northern cod. Paper presented at the Annual Meetings of the American Anthropological Association (15-19 November 1995, Washington, D.C.). [online] URL: http://arcticcircle.uconn.edu/N atResources/cod/mckay.html.

McLeod, K. L., J. Lubchenco, S. R. Palumbi, and A. A. Rosenberg. 2005. Scientific consensus statement on marine ecosystem-based management. Signed by 221 academic scientists and policy experts with relevant expertise and published by the Communication Partnership for Science and the Sea. [online] URL:

http://compassonline.org/pdf files/EBM Consensu s Statement v12.pdf.

Menzies, C. R., editor. 2006. Traditional ecological knowledge and natural resource management. University of Nebraska Press, Lincoln, Nebraska, USA.

Millennium Ecosystem Assessment. 2005. Ecosystems and human well-being: synthesis. Island Press, Washington, D.C., USA.

Mooney, H. A. 1998. Ecosystem management for sustainable marine fisheries. Ecological Applications 8(1):S1-S174.

Moore, G. E. 1903. Principia ethica. Reprinted in 1988 by Prometheus Books, Amherst, New York, USA. [online] URL: http://fair-use.org/g-e-moore/p rincipia-ethica.

Mora, C., R. A. Myers, M. Coll, S. Libralato, T. J. Pitcher, U. R. Sumaila, D. Zeller, R. Watson, K. J. Gaston, and B. Worm. 2009. Management effectiveness of the world's marine fisheries. PLoS Biology 7(6):1-11. 
Morato, T., R. Watson, T. J. Pitcher, and D. Pauly. 2006. Fishing down the deep. Fish and Fisheries 7:24-34.

Morton, A. and J. P. Volpe. 2002. A description of Atlantic salmon Salmo salar in the Pacific salmon fishery in British Columbia, Canada, in 2000. Alaska Fishery Research Bulletin 9:102-110.

Munro, G., and U. R. Sumaila. 2002. The impact of subsidies upon fisheries management and sustainability: the case of the North Atlantic. Fish and Fisheries 3:233-290.

Myers, R. A., and B. Worm. 2003. Rapid worldwide depletion of predatory fish communities. Nature 423:280-283.

National Research Council of the National Academies. 2004. Valuing ecosystem services: toward better environmental decision-making. The National Academies Press, Washington, D.C., USA. [online] URL: http://books.nap.edu/catalog/1 1139.html.

Naylor, R. L., R. J. Goldburg, J. H. Primavera, N. Kautsky, M. C. M. Beveridge, J. Clay, C. Folke, J. Lubchenco, H. Mooney, and M. Troell. 2000. Effect of aquaculture on world fish supplies. Nature 405: 1017-1024.

Neher, P.A. 1996. Fishing quota quality and fishery performance. Reviews in Fish Biology and Fisheries 6:113-116.

Newell, D., and R. E. Ommer, editors. 1999. Fishing places, fishing people. University of Toronto Press, Toronto, Ontario, Canada.

Norse, E. A., C. B. Grimes, S. R. Ralston, R. Hilborn, J. C. Castilla, S. R. Palumbi, D. Fraser and P. Karieva. 2003. Marine reserves: the best option for our oceans? Frontiers in Ecology and the Environment 1(9):495-502.

Ommer, R. E., R. I. Perry, and B. Neis. 2008. Bridging the gap between social and natural sciences: why is this necessary and how can it be done? Pages 177-185 in J. L. Nielsen, J. J. Dodson, K. Friedland, T. R. Hamon, J. Musick, and E. Verspoor, editors. Reconciling fisheries with conservation: proceedings of the fourth world fisheries congress. American Fisheries Society, Symposium 49, Bethesda, MD, USA.

Ostrom, E. 1990. Governing the commons: the evolution of institutions for collective action. Cambridge University Press, New York, New York, USA.

Ostrom, E. 2005. Understanding institutional diversity. Princeton University Press, Princeton, New Jersey, USA.

Ostrom, E. 2007. A diagnostic approach for going beyond panaceas. Proceedings of the National Academy of Sciences 104(39):15181-15187.

Ostrom, E. 2009. A general framework for analyzing sustainability of social-ecological systems. Science 325:419-422.

Palmer, M. A., and S. Filoso. 2009. Restoration of ecosystem services for environmental markets. Science 325(5940):575-576.

Palumbi, S. R., K. L. McLeod, and D. Grunbaum. 2008. Ecosystems in action: lessons from marine ecology about recovery, resistance, and reversibility. BioScience 58(1):33-42.

Pandolfi, J. M., R. H. Bradbury, E. Sala, T. P. Hughes, K. A. Bjorndal, R. G. Cooke, D. McArdle, L. McClenachan, M. J. H. Newman, G. Paredes, R. R. Warner, and J. B. C. Jackson. 2003. Global trajectories of the long-term decline of coral reef ecosystems. Science 301:955-958.

Pauly, D. 2007. The "Sea Around Us" project: documenting and communicating global fisheries impacts on marine ecosystems. Ambio 36(4):290 295.

Pauly, D., J. Alder, E. Bennett, V. Christensen, P. Tyedmers, and R. Watson. 2003. The future of fisheries. Science 302:1359-1361.

Pauly, D., and V. Christensen. 1995. Primary production required to sustain global fisheries. Nature 374:255-257.

Pauly, D., V. Christensen, J. Dalsgaard, R. Froese, and F. Torres, Jr. 1998a. Fishing down marine food webs. Science 279:860-863. 
Pauly, D., V. Christensen, S. Guénette, T. J. Pitcher, U. R. Sumaila, C. J. Walters, R. Watson, and D. Zeller. 2002. Towards sustainability in world fisheries. Nature 418:689-695.

Pauly, D., P. J. B. Hart, and T. J. Pitcher. 1998b. Speaking for themselves: new acts, new actors and a new deal in a reinvented fisheries management. Pages 409-415 in T. J. Pitcher, P. J. B. Hart, and D. Pauly, editors. Reinventing Fisheries Management. Kluwer Academic Publishers, Dordrecht, The Netherlands.

Pauly, D., and J. Maclean. 2003. In a perfect ocean: the state of fisheries and ecosystems in the North Atlantic Ocean. Island Press, Washington, D. C., USA.

Pauly, D., R. Watson, and J. Alder. 2005. Global trends in world fisheries: impacts on marine ecosystems and food security. Philosophical Transactions of the Royal Society B 360:5-12.

Peterman, R., C. N. Peters, C. A. Robb, and S. W. Frederick. 1998. Bayesian decision analysis and uncertainty in fisheries management. Pages 387-398 in T. J. Pitcher, P. J. B. Hart, and D. Pauly, editors. Reinventing fisheries management. Kluwer Academic Publishers, Dordrecht, The Netherlands.

Pierotti, R., and D. Wildcat. 1999. The connectedness of predators and prey: Native American attitudes and fisheries management. Fisheries 24(4):22-23.

Pierotti, R., and D. Wildcat. 2000. Traditional ecological knowledge: the third alternative (commentary). Ecological Applications 10(5):13331340 .

Pikitch, E. K., C. Santora, E. A. Babcock, A. Bakun, R. Bonfil, D. O. Conover, P. Dayton, P. Doukakis, D. Fluharty, B. Heneman, E. D. Houde, J. Link, P. A. Livingston, M. Mangel, M. K. McAllister, J. Pope, and K. J. Sainsbury. 2004. Policy forum ecology: ecosystem-based fishery management. Science 305:346-347.

Pinkerton, E. 1999a. Directions, principles, and practice in the shared governance of Canadian marine fisheries. Pages 340-354 in D. Newell and R. E. Ommer, editors. Fishing places, fishing people. University of Toronto Press, Toronto, Ontario, Canada.
Pinkerton, E. 1999b. Factors in overcoming barriers to implementing co-management in British Columbia salmon fisheries Conservation Ecology 3(2):2.

[online] URL: http://www.ecologyandsociety.org/vol3/ iss2/art2.

Pinkerton, E., and D. N. Edwards. 2009. The elephant in the room: the hidden costs of leasing individual transferable fishing quotas. Marine Policy 33:707-713.

Pinkerton, E., and M. Weinstein. 1995. Fisheries that work. Sustainability through community-based management. The David Suzuki Foundation, Vancouver, British Columbia, Canada.

Pitcher, T. J. 2001. Fisheries managed to rebuild ecosystems: reconstructing the past to salvage the future. Ecological Applications 11(2):601-617.

Pitcher, T. J. 2005. Back-to-the-future: a fresh policy initiative for fisheries and a restoration ecology for ocean ecosystems. Philosophical Transactions of the Royal Society B 360:107-121.

Pitcher, T. J. 2006. An estimation of compliance of the fisheries of Philippines with Article 7 (fisheries management) of the UN code of conduct for responsible fishing. Page 53 (with 18 linked pages) in T. J. Pitcher, D. Kalikoski, and G. Pramod, editors. Evaluations of compliance with the UNcode of conduct for responsible fisheries. Fisheries Centre Research Reports 14(2). University of British Columbia Fisheries Centre, Vancouver, British Columbia, Canada.

Pitcher, T. J. 2008. The sea ahead: challenges to marine biology from seafood sustainability. Hydrobiologia 606:161-185.

Pitcher, T. J., and C. H. Ainsworth. 2008. Back to the future: a candidate ecosystem-based solution to the fisheries problem. Pages 365-383 in J. L. Nielsen, J. J. Dodson, K. Friedland, T. R. Hamon, J. Musick, and E. Verspoor, editors. Reconciling fisheries with conservation: proceedings of the fourth world fisheries congress. American Fisheries Society, Symposium 49, Bethesda, Maryland, USA.

Pitcher, T. J., and C. H. Ainsworth. 2010. Resilience to change in two coastal communities: using the maximum dexterity fleet. Marine Policy 34:810-814. 
Pitcher, T. J., M. R. Clark, T. Morato, and R. Watson. 2010. Seamount fisheries: do they have a future? Oceanography 23(1):134-144.

Pitcher, T. J., P. J. B. Hart, and D. Pauly, editors. 1998. Reinventing fisheries management. Chapman and Hall Fish and Fisheries Series 23. Kluwer Academic Publishers, Dordrecht, The Netherlands.

Pitcher, T. J., D. Kalikoski, G. Pramod, and K. Short. 2009a. Safe conduct? Twelve years fishing under the UN code. World Wildlife Fund, Gland, Switzerland.

Pitcher, T. J., D. Kalikoski, K. Short, D. Varkey, and G. Pramod. 2008. An evaluation of progress in implementing ecosystem-based management of fisheries in 33 countries. Marine Policy 33:223232.

Pitcher, T. J., and D. Pauly. 1998. Rebuilding ecosystems, not sustainability, as the proper goal of fishery management. Pages 311-329 in T. J. Pitcher, P. J. B. Hart, and D. Pauly, editors. Reinventing fisheries management. Kluwer Academic Publishers, Dordrecht, The Netherlands.

Pitcher, T. J., and M. P. Power. 2000. Fish figures: quantifying the ethical status of Canadian fisheries, east and west. Pages 225-253 in H. Coward, R. Ommer, and T. J. Pitcher, editors. Just fish: the ethics of Canadian fisheries. Institute of Social and Economic Research Press, St John's, Newfoundland and Labrador, Canada.

Pitcher, T. J., G. Pramod, D. Kalikoski, and K. Short. 2009b. Not honouring the code. Nature 457:658-659.

Pitcher, T. J., and D. B. Preikshot. 2001. Rapfish: a rapid appraisal technique to evaluate the sustainability status of fisheries. Fisheries Research 49(3):255-270.

Power, M. 2008. Salmon fishing, genomics, and ethics. In J. L. Nielsen, J. J. Dodson, K. Friedland, T. R. Hamon, J. Musick, and E. Verspoor, editors. Reconciling fisheries with conservation: proceedings of the fourth World Fisheries Congress. American Fisheries Society, Symposium 49, Bethesda, Maryland, USA.
Power, M. E., and F. S. Chapin, III. 2009. Planetary stewardship. Frontiers in Ecology and the Environment 7(8):399.

Punt, A. E., J. M. Cope, and M. A. Haltuch. 2008. Reference points and decision rules in the U.S. federal fisheries: west coast groundfish experiences. Pages 1343-1356 in J. L. Nielsen, J. J. Dodson, K. Friedland, T. R. Hamon, J. Musick, and E. Verspoor, editors. Reconciling fisheries with conservation: proceedings of the fourth World Fisheries Congress. American Fisheries Society, Symposium 49, Bethesda, Maryland, USA.

Punt, A. E., and R. Hilborn. 1997. Fisheries stock assessment and decision analysis: the Bayesian approach. Reviews in Fish Biology and Fisheries 7:35-63.

Roberts, C. M. 2001. Designing networks of marine reserves: why small, isolated protected areas are not enough. Conservation Biology in Practice 2:10-17.

Roberts, C. M. 2005. The role of marine reserves in achieving sustainable fisheries. Philosophical Transactions of the Royal Society of London B $\mathbf{3 6 0}$ (1453):123-132.

Roberts, C. M. 2007. The unnatural history of the sea. Island Press, Washington, D.C., USA.

Roberts, C. M., J. A. Bohnsack, F. Gell, J. P. Hawkins, and R. Goodridge. 2001. Effects of marine reserves on adjacent fisheries. Science $\mathbf{2 9 4}$ (5548):1920-1923.

Roberts, C. M., J. P. Hawkins, and F. R. Gell. 2005. The role of marine reserves in achieving sustainable fisheries. Philosophical Transactions of the Royal Society B 360:123-132.

Rose, G. A. 2007. Cod: the ecological history of the North Atlantic fisheries. Breakwater Books, St. John's, Newfoundland and Labrador, Canada.

Rosenberg, A. A. 2007. Fishing for certainty. Nature 449:989.

Rosenberg, A. A. 2009. Changing U.S. ocean policy can set a new direction for marine resource management. Ecology and Society 14(2): 6. [online] 
URL: http://www.ecologyandsociety.org/vol14/iss2/ art6.

Rosenberg,A.A., M. J. Fogarty, M. P.Sissenwine, J. R. Beddington, and J. G. Shepherd. 1993. Achieving sustainable use of renewable resources. Science 262(5135):828-829.

Rosenberg, A. A., and K. L. McLeod. 2005. Implementing ecosystem-based approaches to management for the conservation of ecosystem services. Marine Ecology Progress Series 300:270_ 274.

Royal Commission on Environmental Pollution (RCEP). 2004. Turning the tide: addressing the impact of fisheries on the marine environment. RCEP twenty-fifth report. RECP, London, UK. [online] URL: www.rcep.org.uk/reports/25-marine/25marine.htm.

Ruckelshaus, M., T. Klinger, N. Knowlton, and D. P. DeMaster. 2008. Marine ecosystem-based management in practice: scientific and governance challenges. BioScience 58(1):53-63.

Ruddle, K. 1998a. Introduction to the special issue on a modern role for traditional coastal-marine resource management systems in the Pacific Islands. Ocean and Coastal Management 40:99103.

Ruddle, K. 1998b. The context of policy design for existing community-based fisheries management systems in the Pacific Islands. Ocean and Coastal Management 40:105-126.

Ruddle, K. 1998c. Traditional community-based coastal marine fisheries management in Viet Nam. Ocean and Coastal Management 40:1-22.

Ruddle, K., and S. Segi. 2006. The management of inshore marine recreational fishing in Japan. Coastal Management 34:87-110.

Russ, G. R. 2002. Yet another review of marine reserves as reef fishery management tools. Pages 421-443 in P. F. Sale, editor. Coral reef fishes: dynamics and diversity in a complex ecosystem. Academic Press, San Diego, California, USA.

Sáenz-Arroyo, A., M. C. Roberts, J. Torre, M. Cariño-Olvera and $R$. Enríquez-Andrade. 2005a. Rapidly shifting environmental baselines among fishers of the Sea of Cortez. Proceedings of the Royal Society 1726:1-6.

Sáenz-Arroyo, A., C. M. Roberts, J. Torre and M. Cariño-Olvera. 2005b. Using fishers' anecdotes, naturalists' observations and grey literature to reassess marine species at risk: the case of the Gulf grouper in the Gulf of California, Mexico. Fish and Fisheries 6:121-133.

Sainsbury, K. 1998. Living marine resource assessment for the 21st century: what will be needed, and how will it be provided? Pages 1-41 in T. J. Quinn, II, F. Funk. J. Heifetz, J. N. Ianelli, J. E. Powers, J. F. Schweigert, P. J. Sullivan, and C.I. Zhang, editors. Fishery stock assessment models. Alaska Sea Grant, Fairbanks, Alaska, USA.

Sainsbury, K., and U. R. Sumaila. 2003. Incorporating ecosystem objectives into management of sustainable marine fisheries, including "best practice" reference points and use of marine protected areas. Pages 343-360 in M. Sinclair and G. Valdimarsson, editors. Responsible fisheries in the marine ecosystem. Food and Agriculture Organization, Rome, Italy.

Schnute, J. T., and L. J. Richards. 1994. Stock assessment for the 21 st century. Fisheries 19:10-16.

Schreiber, D. K. 2001. Co-management without involvement: the plight of fishing communities. Fish and Fisheries 2(4):376-384.

Sherman, K. 1995. Achieving regional cooperation in the management of marine ecosystems: the use of the large marine ecosystem approach. Ocean and Coastal Management 29:165-185.

Sibert, J., J. Hampton, P. Kleiber, and M. Maunder. 2006. Biomass, size, and trophic status of top predators in the Pacific Ocean. Science 314:1773-1776.

Sims, D. W., and A. J. Southward. 2006. Dwindling fish numbers already of concern in 1883 . Nature 439:660.

Sissenwine, M. P., and P. M. Mace. 2003. Governance for responsible fisheries: an ecosystem approach. Pages 363-390 in M. Sinclair and G. Valdimarsson, editors. Responsible fisheries in the marine ecosystem. Food and Agriculture Organization, Rome, Italy. 
Sivertsvik, M., W. K. Jeksrud, and J. T. Rosnes. 2002. A review of modified atmosphere packaging of fish and fishery products-significance of microbial growth, activities and safety. International Journal of Food Science and Technology 37 (2):107-127.

Snyder, R., D. Williams, and G. Peterson. 2003. Culture loss and sense of place in resource valuation: economics, anthropology, and indigenous cultures. Pages 107-123 in S. Jentoft, H. Minde, and R. Nilsen, editors. Indigneous peoples: resource management and global rights. Centre for Sami Studies, University of Troms $\varnothing$, Norway.

Starkey, D. J., P. Holm, and M. Barnard, editors. 2008. Oceans past: management insights from the history of marine animal populations. Earthscan, London, UK.

Sumaila, U. R. 2004. Intergenerational costbenefit analysis and marine ecosystem restoration. Fish and Fisheries 5:329-343.

Sumaila, U. R. 2005. Differences in economic perspectives and implementation of ecosystembased management of marine resources. Marine Ecology Progress Series 300:279-282.

Sumaila, U. R. 2007. Getting values and valuation right: a must for reconciling fisheries with conservation. American Fisheries Society Symposium 49:587-592.

Sumaila, U. R., and A. T. Charles. 2002. Economic models of marine protected areas: an introduction. Natural Resource Modeling 15(3):261-272.

Sumaila, U. R., A. Khan, R. Watson, G. Munro, D. Zeller, N. Baron, and D. Pauly. 2007. The World Trade Organization and global fisheries sustainability. Fisheries Research 88:1-4.

Sumaila, U. R., and C. Walters. 2005. Intergenerational discounting: a new intuitive approach. Ecological Economics 52:135-142.

Sutinen, J. G., and M. Soboil. 2003. The performance of fisheries management systems and the ecosystem challenge. Pages 291-309 in M. Sinclair and G. Valdimarsson, editors. Responsible fisheries in the marine ecosystem. Food and Agriculture Organization, Rome, Italy.
Trosper, R. L. 2002. Northwest coast indigenous institutions that supported resilience and sustainability. Ecological Economics 41:329-344.

Trosper, R.L. 2009. Resilience, reciprocity and ecological economics: Northwest coast sustainability. Routledge, London, UK and New York, New York, USA.

United Nations Environment Programme (UNEP). 2009. Climate change science compendium 2009. UNEP, Geneva, Switzerland.

Walters, C. J. 2007. Is adaptive management helping to solve fisheries problems? Ambio 36 (4):304-307.

Walters, C. J., V. Christensen, S. J. Martell, and J. F. Kitchell. 2005. Possible ecosystem impacts of applying MSY policies from single-species assessment. ICES Journal of Marine Science 62:558-568.

Walters, C. J., and J. J. Maguire. 1996. Lessons for stock assessment from the northern cod collapse. Reviews in Fish Biology and Fisheries 6(2):125137.

Walters, C. J., and S. J. D. Martell. 2004. Fisheries ecology and management. Princeton University Press, Princeton, New Jersey, USA.

Ward, T., D. Tarte, E. Hegerl, and K. Short. 2002. Policy proposals and operational guidance for ecosystem-based management of marine capture fisheries. World Wide Fund for Nature, Sydney, Australia.

Watson, R., J.Alder, and D. Pauly. 2006. Fisheries for forage fish, 1950 to the present. Pages 1-20 in J. Alder, and D. Pauly, editors. On multiple uses of forage fish: from ecosystems to markets. Fisheries Centre Research Reports 14(3). University of British Columbia Fisheries Centre, Vancouver, British Columbia, Canada.

Watson, R., and Pauly, D. 2001. Systematic distortions in world fisheries catch trends. Nature 414:534-536.

Weber, M. L., and S. Iudicello. 2005. Obstacles and opportunities for community-based fisheries management in the United States. Coastal 
Enterprises, Inc., Portland, Maine, USA. [online]

URL: http://www.ceimaine.org/images/stories/pdf/

CommunityBasedFisheriesManagementReport.pdf

Wilson, D. C., J. R. Nielsen, and P. Degnbol, editors. 2003. The fisheries co-management experience: accomplishments, challenges, and prospects. Kluwer Academic Publishers, Dordrecht, The Netherlands.

Wilson, J. 2007. Scale and costs of fishery conservation. International Journal of the Commons 1:29-41.

Winterhalder, B., and E. A. Smith. 2002. Analyzing adaptive strategies: human behavioral ecology at twenty-five. Evolutionary Anthropology 9(2):51-72.

Wood, L. J. 2007. MPA Global: a database of the world's marine protected areas. Sea Around Us Project, UNEP-WCMC and WWF. [online] URL: www.mpaglobal.org.

Wood, L. J., and S. Dragicevic. 2007. GIS-based multicriteria evaluation and fuzzy sets to identify priority sites for marine protection. Biodiversity and Conservation 16:2539-2558.

Wood, L. J., L. Fish, J. Laughren, and D. Pauly. 2008. Assessing progress towards global marine protection targets: shortfalls in information and action. Oryx 42(3):1-12.

Wyman, K. M. 2008. The property rights challenge in marine fisheries. Arizona Law Review 50(2):511543.

Young, O. R. 2002. The institutional dimensions of environmentalchange: fit, interplay, and scale. MIT Press, Cambridge, Massachusetts, USA. 